\title{
أثر استخدام بيئة تعلم افتراضية في تدريس الاقتصاد المنزلي على \\ التحصيل المعرفي و تحسين جودة الحياة لدى طالبات \\ شعبة التأهيل التربوي بكلية التربية بسوهاج
}

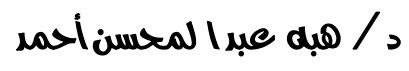

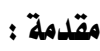

وتوفر نوعاً من التواصــل و التقاعـلـل بــين

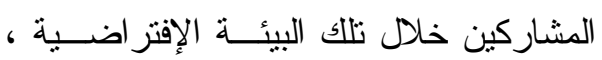

وكأنهم موجودين في مكان و احد يعملون معًا

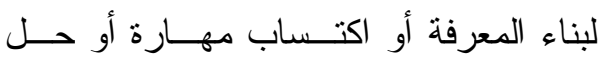
مشكلة تحت إثر اف المعلم عن بعد (حسـن التهن

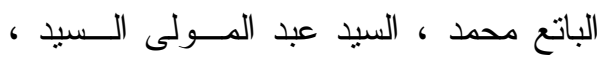

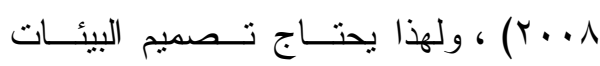
التعليمية الافتر اضية إلى الإعداد الجيد مـنـ

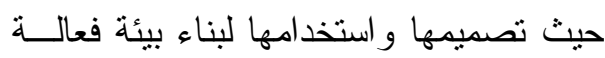

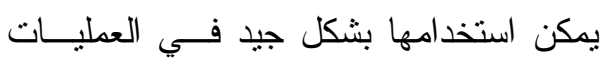

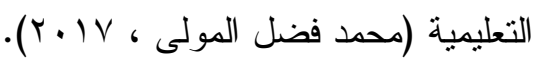
ويعدُ التعلم الافتز اضي وسيلة هادفـــة

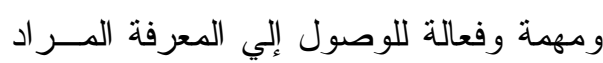

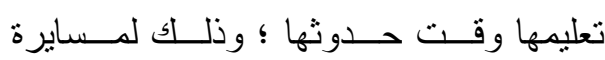
متغير ات ومستجدات ذلك العــصر ، وتَعُــــ المجتمعات التي لا نوظف تقنيات و إمكانيات و أساليب التعلم الافتر اضي مجتمعات تحتــاج إلى مر اجعة سياستها التعليمية لوضع الخطط

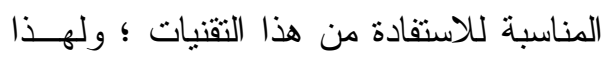
اهتمت المجتمعات العالمية بالتعلم الافتر اضي مني
إن التطــــور الـــسريع فــي مجـــال

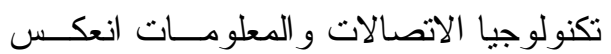

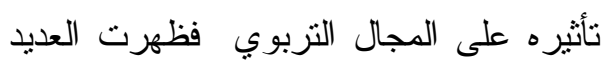
من أنماط وطرق التعلم الجديدة التي شجعت

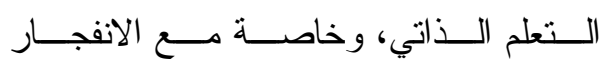

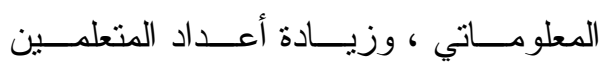
وحاجتهم إلى بيئات تعليمية توفر المزيد من الخبرات ومصادر التعلم المتتوعة. ومن أبرز التطبيقات التكنولوجيه فـي التعلم و التعليم - التعلم الإككتروني وتطبيقاته

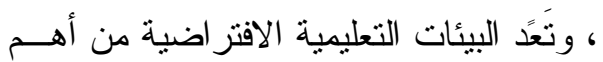

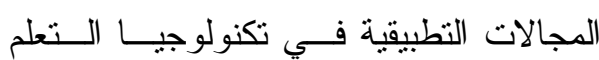
الإلكتروني، حيث أنها تعتمد على اســتخدام

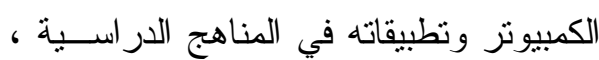

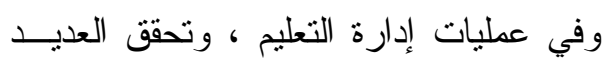

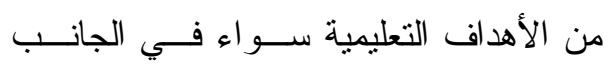
المعرفي أو المهاري و التذريبي أو الوجداني

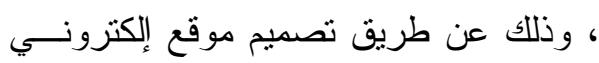

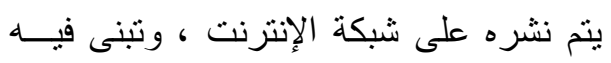

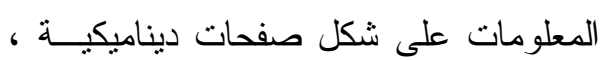




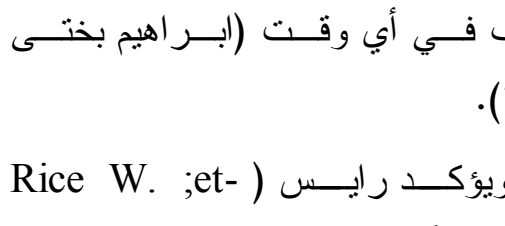

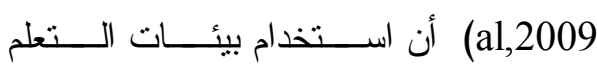

الافتر اضي في العملية التعليمية تجعل المتعلم

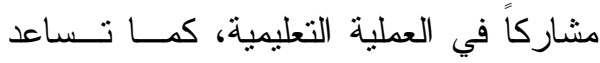
أيضاً في وصول العملية التعليمية لأكبر عدد

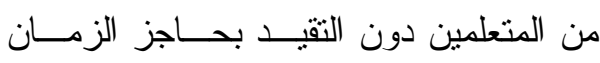

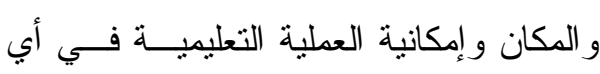

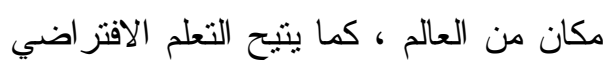

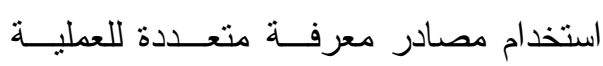
التعليمية .

كما استخدم التعلم الافتز اضــي فـي مرحلة التعليم الجامعي فظهرت الجامعـات

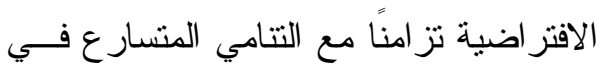
تكنولوجيا الاتصالات وتطبيقاتها على الثبكة

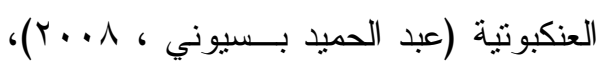
وتعُّ بريطانيا أول من أنشئت جامعة للتعليم اعني

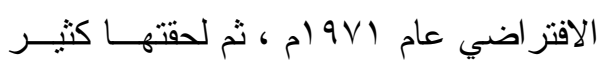

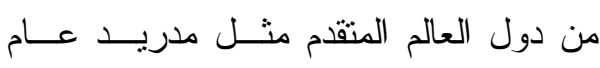

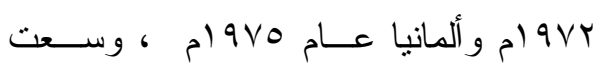
الكثير من الــدول لتفعيـل دور الجامعــات الافتر اضية في التعليم العالي لما تتمتع به من دن

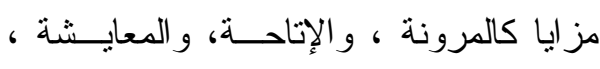

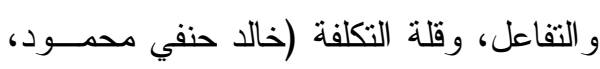

$\cdot(r \cdot 17$
لما له من أهمية كبيرة ومميز ات كثيرة جعلته محل اهتمام المؤسسات العالمية والإقليميـــة .(Young P. A,2009) و التعلم الافتر اضي يوفر بيئـــة تعلم تفاعلية تسمح للمتعلم بالدر اسة في الوقت

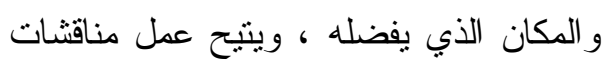

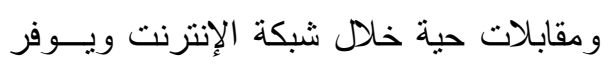

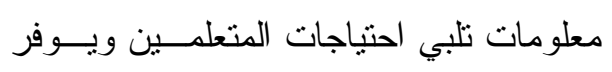
بر امج المحاكاة و الصور المتحركة وتمــارين

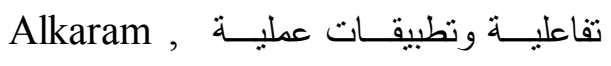
.(A.M., \& Al- Ali N.M. 2001) ويتيح التعلم الإفتز اضـــي للمتعلمـين ممارسة التعلم الــذاتي و اكتهـــاب المفــاهيم و الحقائق و المهار ات التي يصعب اكتـسابها من خلاص طرق التعلم التقليدية ؛ ولهذا فهو

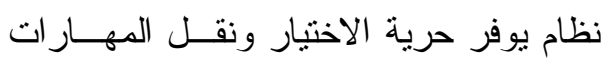

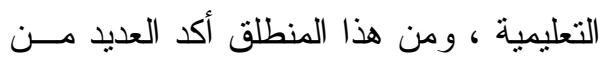
العلماء على ضرورة الأخذ بنظــام الــتعلم الافتر اضي لتحقيق أفضل النتائج في العمليــة التعليمية . ويهدف التعلم الافتز اضي إلي زيــادة

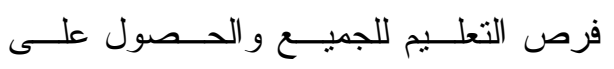

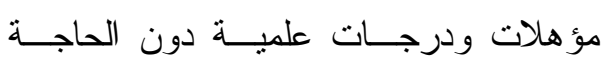
للاهاب إلي المؤسسات التعليميــة، فــالتعلم الافتز اضي يعد بمثابة مر اكز تعليم مفتوحسـة

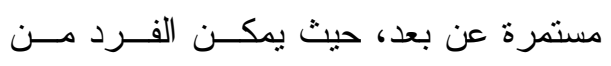

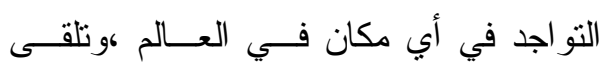




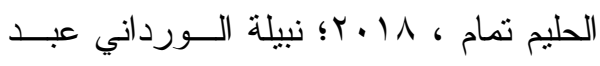

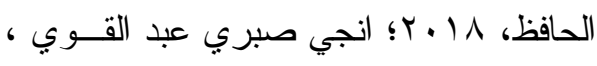

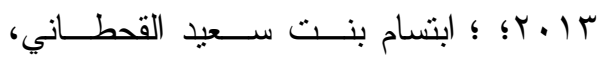

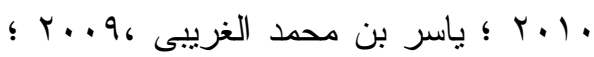

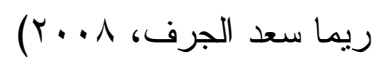

وعلى الجانب الآخر أكد الكثير مـن

الباحثين و المتخصصون في مجـــال التتميــة

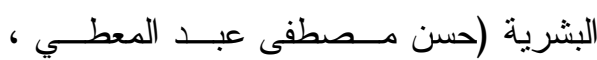

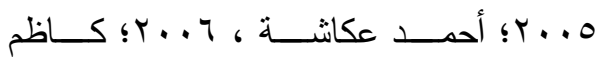

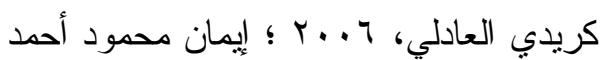

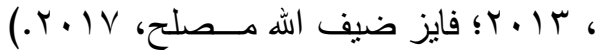

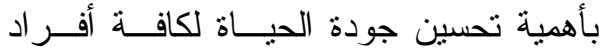
المجنمع ، وينطوي مفهوم جودة الحياة على شعور الشخص بالكفـــاءة الذاتيـــة وإجـــادة

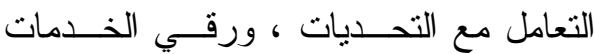

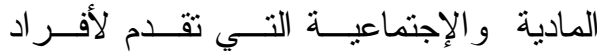
المجتمع ، و إحساس الفرد بالرضـا و التحــسن

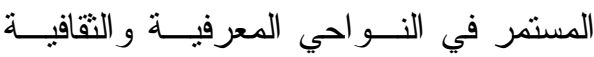
و التعليمية ؛ لذا فالتعلم الافتز اضي يساهم في تحسين جودة الحياة حيث يساعد في التغلــبـ على الكثير من مــشكلات الــتعلم النقليــدي وشعور المتعلم بالرضا و السعادة أثناء التعلم

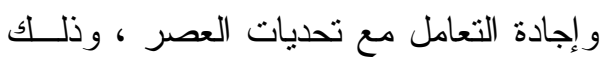

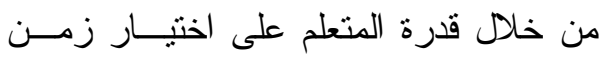
ووقت التعلم وتتوع مصادر ووسائل الــتعلم وتوفر بيئة غنية بالمثير ات التي تشعر المتعلم
و الاستخدام الفعال للتعلم الافتراضــي

في التعلــيم الجــامعي يُمَكــن المتعلمــين

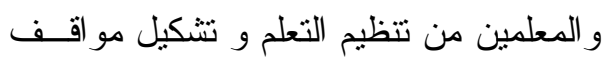
تعليمية قادرة على حل وضعيات أو مشكلات عملية في الحياة الجامعية أو خارجها، تعبــر عن إبداع المتعلم، و التي من الممكن وضعها

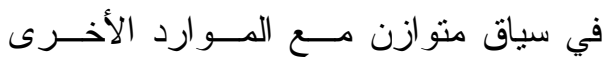
الموجودة داخل النظام، و إعادة استخدامها و مشاركتها مع الأقران أو المعلمـين (هيـام

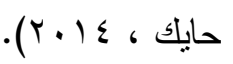
وقد أكدت نتائج كثير من الدراســات على أهمية التعلم باســتخدام بيئـات الــتعلم الافتر اضي في التتمية البـشرية المسـتدامة

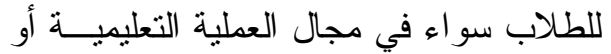

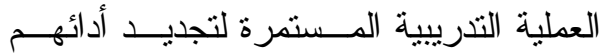
المهني و التعليمي ومـسـاعدتهم فــي النـــو

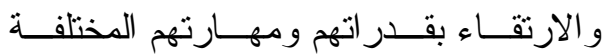
بأســـاليب متعـــدة لهـــا صــفة التكامــلـل و الاستمر ارية و الثمول و التكيف و المرونـــة

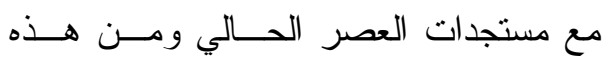

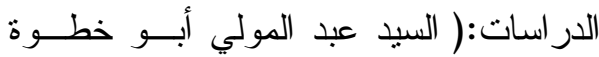
Potter C. \&Naido, G. ؛ Y.Ir。 ؛ Sarikaya ， O, 2010 2012 .(Richard , F. 2005 و هناك در اسات عديدة نؤكد نتائجهـــا أهية بيئات التعلم الافتر اضي فــي العمليــة التعليمية ومن هذه الدراسات: (شادية عبــــ 
على أثز استخدام بيئة التعلم الافتز اضية فـي تدريس الاقتصاد المنزلي علــى التحــصيل المعرفي وتحسين جودة الحياة. مشكلة البحث:

أنشأت شعبة التأهيل التربوي بكليـــة

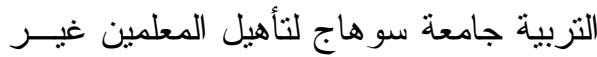

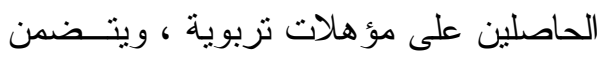

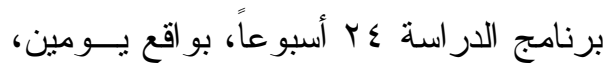
أيام الجمعة و السبت فقط من كل أسبوع، وقد لاحظت الباحثة عند تدريسها مقرر الاقتصاد

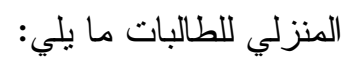

- ضيق الوقت المخــصص لتـدريس

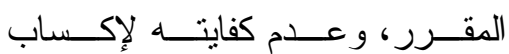

الطالبـــات المعلومــــات و المهـــــار ات الات المنضمنه بالمقرر .

- عدم انتظام الطالبات الملتحقين بشعبة التأهيل التزبـــوي بـسب انسـشغالهم بظروفهم المهنية أو الاجتماعية . - تذني مستوى الطالبــات و انخفــاض درجاتهن في الاختبار النهائي للمقرر . و برزت مشكلة الدر اسة أيضًا عندما

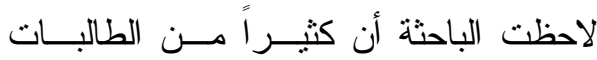
المترددين غير راضين وغيـر مـستمتعين

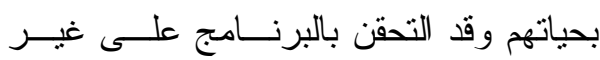

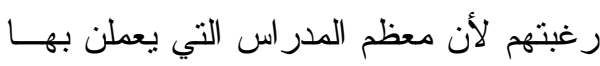
أرغنهن على استكمال تعليمهم الجامعي أو لون لأن
بالرضـا و القدرة على مواصــلـة الــتـعلم فــي ظروف و إمكانات أفضل.

ويعد الاقتصاد المنزلي من العلوم التي

تسهم في تحقيق مفهوم جودة الحياة للمتعلمين

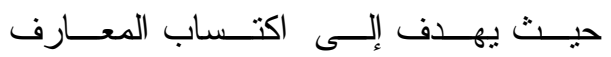
و المهـــار ات العمليــة المرتبطــــة بمجالاتـــهـ

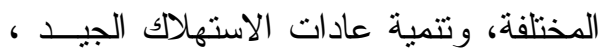
و الاهتمام بتحسين الوعي بالو اقع المعيـشي لـي و القضايا المعاصرة و التحديات العالمية التــي تؤُثر على الأسرة منل (الزواج- الإنجــاب-

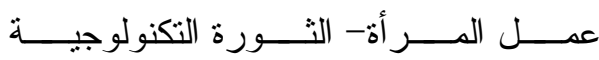

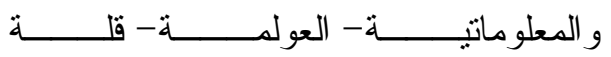
الموارد.................... ، و وغير ها) .

كما تشجع در اسة الاقتصساد المنزلــي

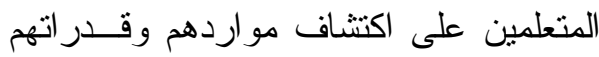
الخاصة ، وتطوير ها لاستخدامها في حياتهم

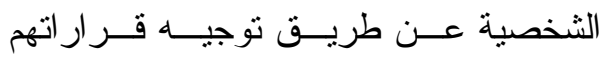
وتصرفاتهم بهدف إعدادهم للحيــاة الحاليـــة

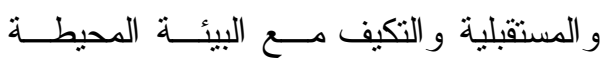

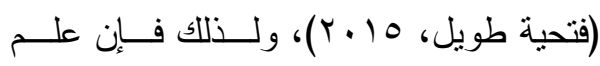

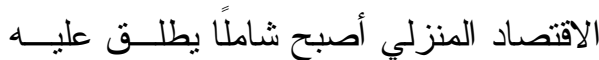

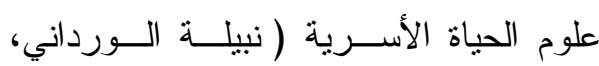
.$(r \cdot .9$ ونظرًا لأهميــة دراســـة الاقتــصـاد

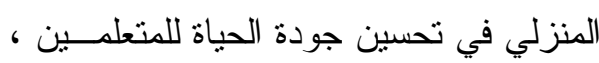
و المز ايــا التــي يحققهــــا اســتخدام الــتـعلم

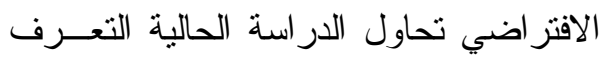




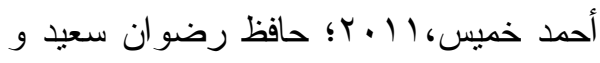

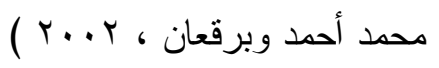

و رغم توفر المستحدثات التكنولوجية

إلا أن الأساليب التقليدية في التدريس ماز الت

هي المسيطرة ، حيث تؤكد (زيزي حسني

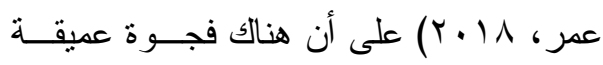

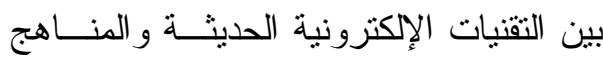
الدراسية بشكل عام ومنهج الاقتصاد المنزلي

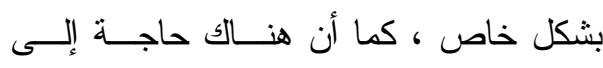

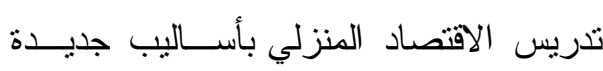
تو اكب التطور التكنولوجى وتقدم واحتياجات المجتمع من خلال طرق ومداخل تساعد في تحقيق أهدافه وتطبيقات مجالاته المختلفة مثل

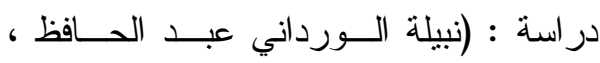

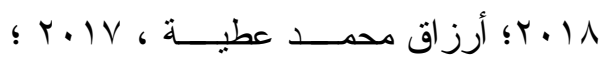

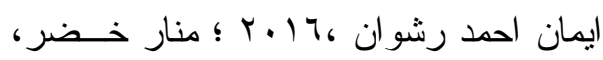
$\cdot(r \cdot) r$ كما أوصت در اسة كل من (ألفت بنت

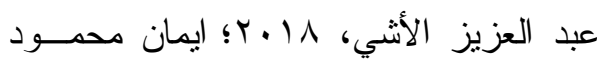

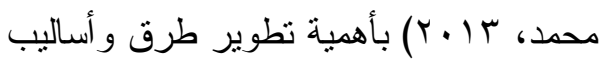

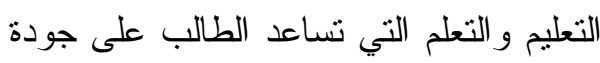

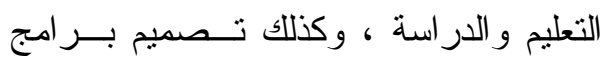

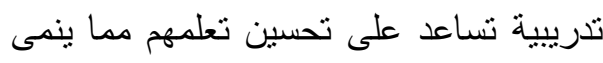
الشعور لايهر بجودة الحياة. تحديد مشكلة البحث:

تحددت مشكلة البحــث الحــالي فـي انخفاض مسنوى التحصيل المعرفي وجــودة
الفصل كل هذا كان كفيلاً بأن يعـبقهن عـن معايشة جودة الحياة بإيجابية وفاعلية. وللتحقق مما لاحظته الباحتـــة قامــت الباحث بتطبيق مقياس جودة الحيــاة لطلبـــة

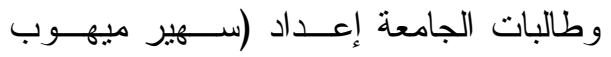

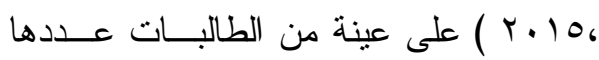

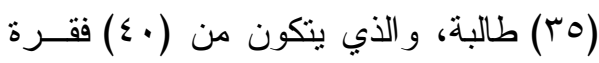
موزعة على أربعة أبعاد هى: جودة الصحة من لأكة

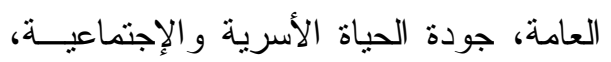

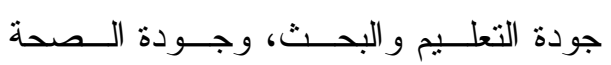

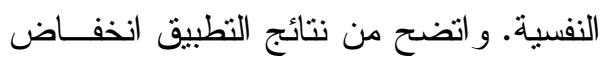

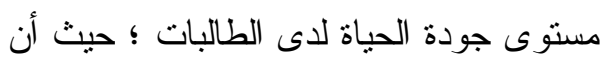
عدد الطالبات اللاتي حصلن علـى (.0\%) فأكثر من الدرجة الكلية عددهن (r ا ( طالبة. كما يرى كل من لو اســاكي (2007)

Tayler M, وتــايلور (Lwasski Y.

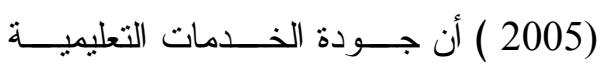
و التتمية البشرية من أهم العوامل التي نؤدي إلى تحسين جودة الحياة. ومن هنا تأني الحاجة إلى تتمية جودة

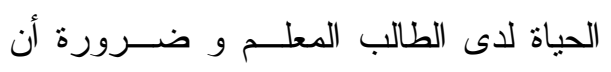

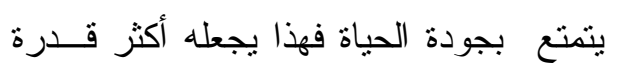

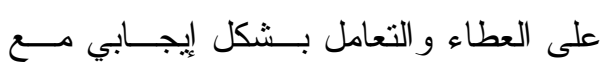
المتعلمين ويؤكد على ذلك در اسة (عبـــــ الله

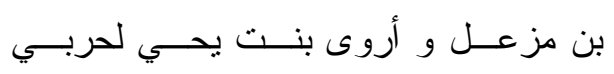

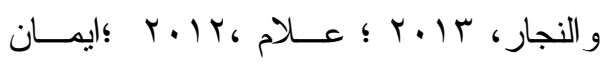


المجموعة التجريبية اللاتــي درســن بو اســـة بيئــة الــتعلم الافتز اضــــية وطالبات المجموعة الضابطة اللاتـي ليـي درسن بالطريقة التقليدية r. توجد فروق ذات دلالة إحصائية عند بله مستوى دلالة (205) في مقيــاس جودة الحياة بين طالبــات المجموعـــة التجريبية اللاتي درسن بواسطة بيئــة التعلم الافتر اضي وطلاب المجموعـــة الضـابطة اللاتــي درســن بالطريقــة التقليدية

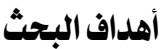

$$
\text { هدف البحث الحالي إلي ما يلي: }
$$

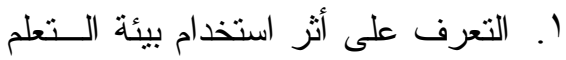

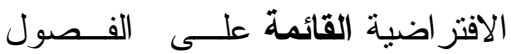

الإفتز اضــية فـي تتميــة التحــصيل

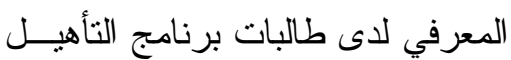

$$
\text { التربوي بكلية التربية بسو هاج • }
$$

r. التعرف على أثز استخدام بيئة الــتعلم

الافتز اضية القائمة علـى الفـصول

الإفتر اضية في تحسين جودة الحيــاة

لدى طالبات برنامج التأهيل التربـــوي جـي

$$
\text { بكلية التربية بسو هاج • }
$$

أهمية البحث:

تمثلت أهمية هذا البحث فيما يلي:

1. مو اكبه التطورات التكنولوجية الحديثة

، في التتمية البشرية بمؤسسات التعليم
الحياة لدى طالبات شعبة التأهيــل الثزبــــي

$$
\text { بكلية التربية بسوهاج ل }
$$

لذا يسعى البحث الحالي إلى تحسـين

التحصيل المعرفي وجودة الحياة من خــلال

استخدام بيئة تعلم افتر اضــية فـي تــدريس

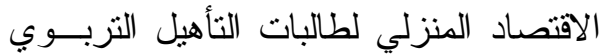

بكلية التربية بسو هاج.

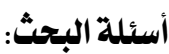

يحاول البحث الحالي الإجابة عن الأســـلة

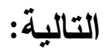

- ما مأثز استخدام بيئة تعلـــم افتر اضــية

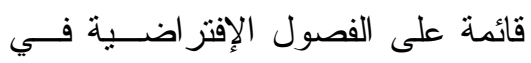

تتمية التحصيل المعرفي لدى طالبــات

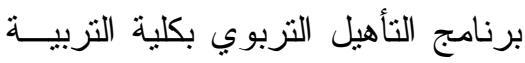

$$
\text { بسو هاج ؟ باج }
$$

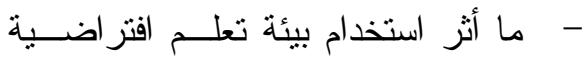

قائمة على الفصول الإفتر اضــية فــي تلعي

تحسين جودة الحيــاة لــدى طالبــات الرقات

برنامج التأهيل التزبوي بكلية التربيــة

$$
\text { بسو هاج. }
$$

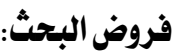

للإجابة عن أسئلة البحث يجب التحقى مسن

$$
\text { صحة الفروض الآتية: }
$$

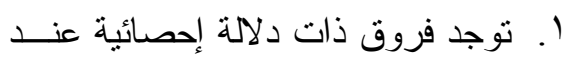

مستوى دلالة (0.05) في التحصيل

المعرفي التحــصيلي بــين طالبــات 


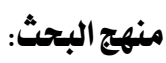

نظر اً لطبيعة البحث و الأهداف الـــي

يسعي لتحقيقها، استخدمت الباحثـــة المــنهزج

الوصفي في إعداد الخلفية النظريسـة للبحــث

ومو اده و أدو اته التعليمية ، وكـــللك اســتخدم

المنهج التجريبي للكثف عن أنتر اســتخدام

بيئة التعلم الافتزر اضي فــي تــدريس مقــرر

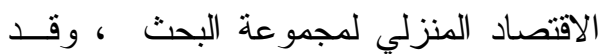

استخدم التصميم التجريبي ذي المجمــوعتين

الضابطة و التجريبية.

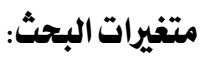

المتغيرات المستقلة: وهي بيئة الــتعلم

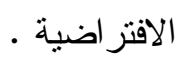

المتغيرات التابعة: التحصيل المعرفي -

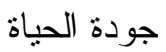

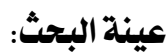

قامت الباحثة باختيار عينة البحث من

الطالبات المسجلين ببرنامج التأهيل التزبـــوي

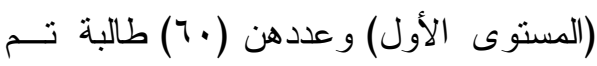

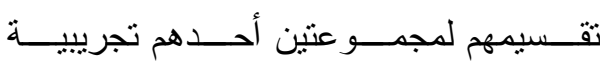

$$
\text { والأخرى ضابطة. }
$$

المواد التعليمية وأدوات البحث:

\section{لتحقيق أهداف البحث والتحقق من صــحة}

فروضه، أعلات الباحثة الأدوات التالية:

ا . ببيئة تعلم افتراضية لتـدريس مقـرر

الاقتصـاد المنزلـــي لطالبــات برنــامج

$$
\text { التاهيل التزبوي. }
$$

العالي لتحقيق أفضل النتائج لتخــريج

كو ادر قادرة على العمـلـل ومو اجهـــة تحديات العصر بكفاءة .

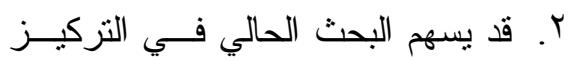

على أهية تحسين جـودة الحبــاة

للطالب و المعلم لتأثنير ها علــى آدائـــه

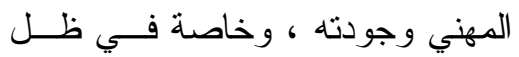

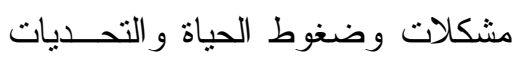

المعاصرة التي نو اجه الفرد.

r. قد تفيد ما يتم التوصل اليه من نتــائج

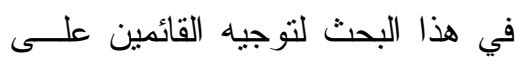

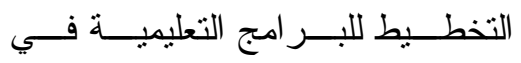

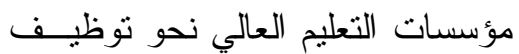

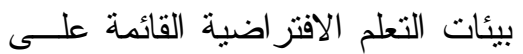

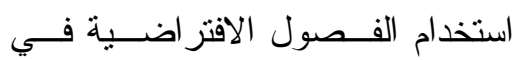

العملية التعليمة لرفع جودة الخــدمات

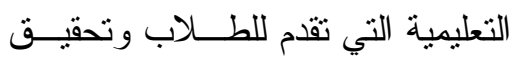

$$
\text { الأهداف التعليمية . }
$$

ع. تصميم نموذج لبيئة تعلم افتر اضي في العي

تدريس الاقتصاد المنزلي ، و الاستفادة

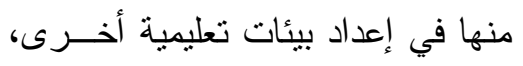

تستقيد من تقنيات التعلم الإككترونــي لعي

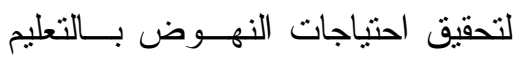
وجودته في التعليم الجامعي.

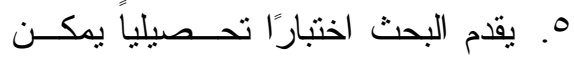

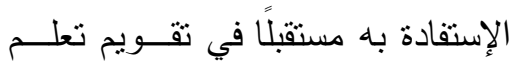

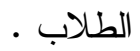


ـ- إجر اء التعديلات التي أوصـى بهــا

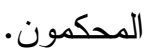

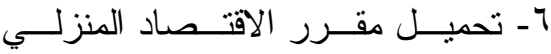

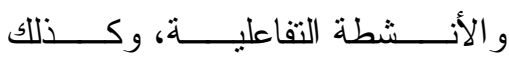

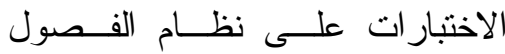

$$
\text { الافتز اضية. }
$$

V- تطبيق تجربة البحث، وهذا يتضمن: - اختبار عينة من طالبات برنــامج

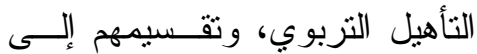
مجمـــو عتين إحــــاهما تجريييـــة،

$$
\text { و الأخرى ضابطة. }
$$

للتأكد من تكافؤ المجموعنين.

- التــدريس للمجموعـــة التجريبيـــة بالبيئـــة الافتر اضـــــة المـــصمعة و المجموعة الــضابطة بالطريقــة التقليدية.

- تطبيق أدوات البحث تطبيقًا بعًَيا. A- تحليل وتفسير النتائج. 9 - تقديم بعض المقترحات التوصيات. حدود البحث:

اقتصر البحث الحالي على الحدود التالية ا. عينة من طالبــات برنــامج التأهيــل

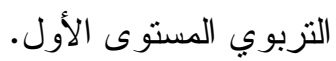

r. اختبار تحــصيلي إليكترونــي لقيــاس

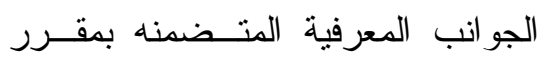

الاقتصـاد المنزلي (إعداد الباحثة).

r. مقياس جودة الحياة إعداد (محمود عبــــ

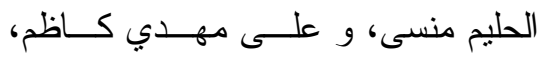

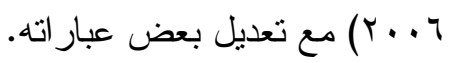

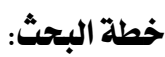

لتحقيق أهـــاف البحـث والإجابـة عـن

تساؤلاته، واختبار صحة فروضه تم إتبــاع

الإجر اءات التالية:

1- الإطلاع على الأدبيات و الدراســات

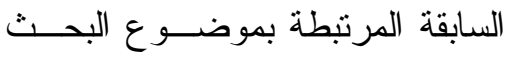

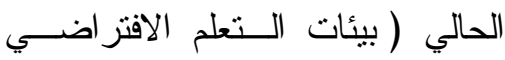

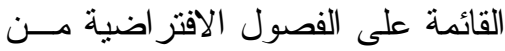

حيث المفهوم والخصائص وخطوات

\section{(التطبيق).}

r- تصميم بيئة التعلم الإككتروني وفًّــا

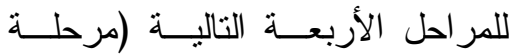

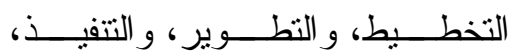

$$
\text { و التقويم). }
$$

r- إعداد أدوات البحث اختبار تحــصيلي

ومقياس جــودة الحيــاة ، و الــضبط

$$
\text { الإحصائي لها. }
$$

ع- إرسال المحتوى المبرمج و الأنـشطة

التفاعلية و الاختبار ات إلى مجموعـــة

من المحكمين المتخصصين لمعرفــة

آر ائهم. 
المنطورة التي تسنطيع أن تقدم قيمة مضافة على التعليم بالطرق التقليدية.

ويعرفهـــا علـــى ســـالم الــشهري

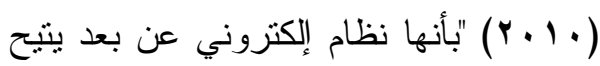

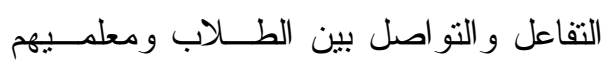
بالصوت و الصورة بشكل متز امن" .

يعرفها ويللر (Weller, M 2007 )

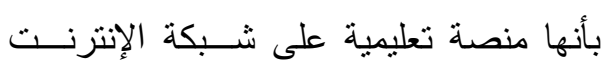

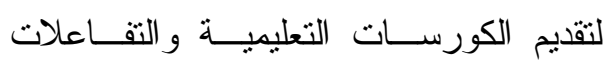
والأنشطة داخل نظام متكامل مع توفير طرق ولفر

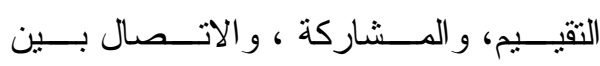
المتعلمين.

وتعرفها ســارا (Sara J., 2019)

هي نظام عبر الإنترنت يسمح بنقل المــواد

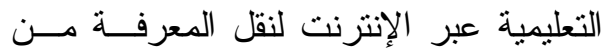

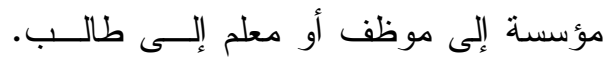

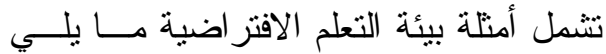
و أكثر ، ويمكن الوصول إلى كل ذللك عبــر

نظام منصل بالإنترنت أو جهاز كمبيوتر

وتعرفها الباحثة إجرائًاً بأنها " نظم

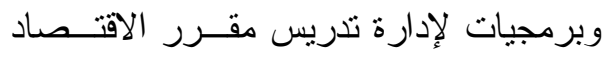

المنزلي على شـبكة الإنترنــت باســتخدام

برنــامج ســكولوجى Schoology ويتـيح

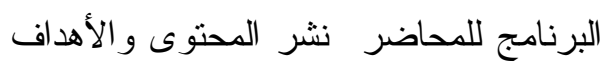

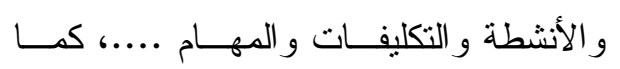

r. قيــاس التحــــيل المعرفــي فــي

مستويات: التذكر - الفهم - النطبيــق التقييم.

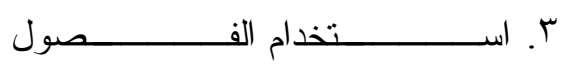
الافتر اضية Schoology كبيئة تعلـــ افتر اضية. مصطلحات البحث إنث

Virtual

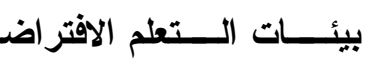
learning environment تعرفها غادة النفيعى (Y I r ) "بأنها بيئات مصممة من مجموعة مــن الأنظمــة

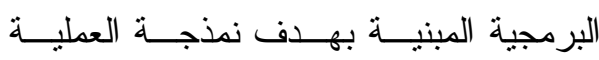
التعليمية التقليدية من خلال دمج مجموعة من

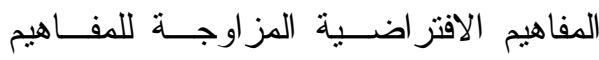
التقليدية ، بحيث تكون تلك الأبوات متاحسـة

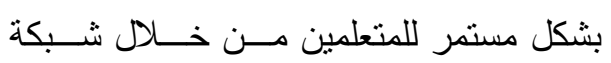

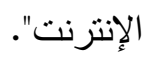

تعرفها حليمه يوسـف المنتـشري

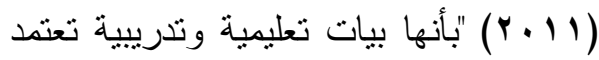

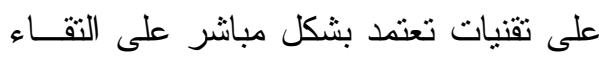

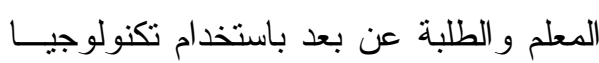

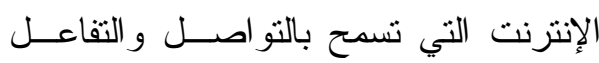
بشكل منز امن أو غير منز امن". ويعرفها ابراهيم أحمد نوار (T) بأنها طريقة لتوصيل العلم عن طريق شـبكة

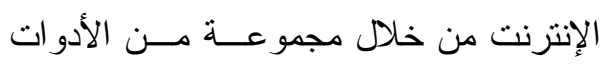


وثو ابتهـه ومعتقداته، وتــشمل أوجــه الحالـــة النفسية ومستوى الاستقلال الثخصي".

يعـــ لونجـــت (

Longest.

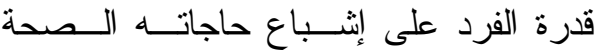

النفسية مثل الحاجات البيولوجية و العلاقــات الاجتماعية الإيجابية والاستقرار الاقتصادي،

و القدرة على مقاومة الــضنغوط الاجتماعيـــة و الاقتصادية ويؤكد أن شعور الفرد بالصحة النفسية يعد من المؤشرات القوية الدالة على

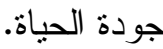

وتناولت عبير أحمد أنور، وفاتن عبد

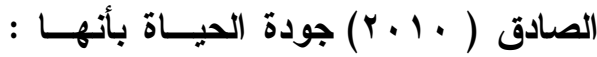

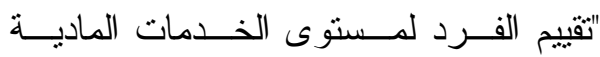

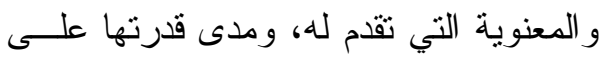
إنثباع حاجاته الذانية و الموضـــــية، وفــي

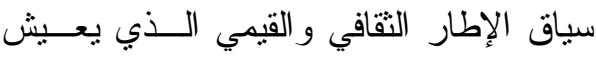
فيه، و انعكاس ذلك علـى حالتـــه الــصحية و النفسية و علاقاته الاجتماعية وتو افقـهـه مـــع

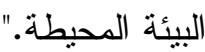

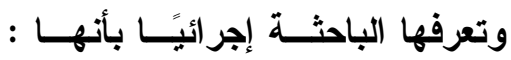

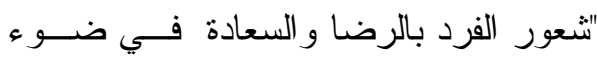

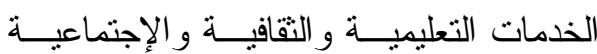

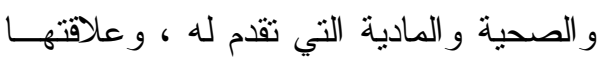
بأهد افه وتوقعاته ومعاييره و اهتماماته ، وذللك

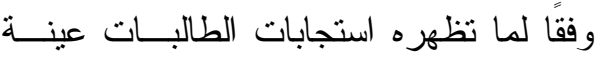

يتمكن المـتتعلم مــن التـشارك و التفاعـلـل و الاتصال بطريقة متز امنة أو غير منز امنة . جودة الحياة Quality of life

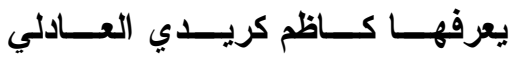

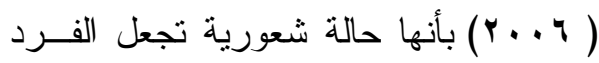
يرى نفسه قادرًا على إثباع حاجاته المختلفة

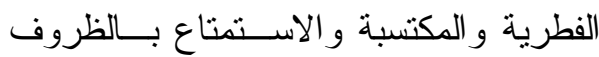

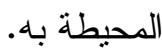

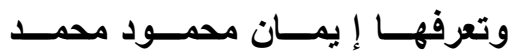

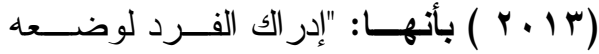
الحالي في ضوء النظام التعليـــي و الثقــافي الذي يعيش فيه و علاقته بأهدافــهـ وتوقعاتـــه

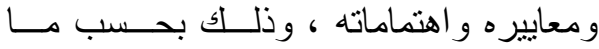
تظهره استجابة المعلمين على مقياس جـودة

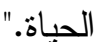

وتعرفها منظمة الصحة العالميــة

(Anthill, et al, 2007: 177) WHO (جودة الحياة بأنها : " قــدرة الفــرد علــى (A) الاستمتاع بالإمكانيات المتاحة لديه في الحياة وشعوره بالأمن و الرضا و السعادة و الرفاهية حتى لو كاف لديه ما يعوق ذلك." يعرفها ديللر ( Dialer S., 2009 بأنها : " الإدر اكات الحسـية للفـرد تجـــاه مكانته في الحياة من الناحية الثقافية، ومسن

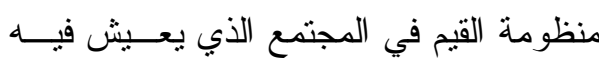

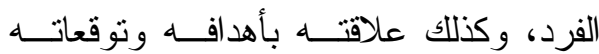


• تثت افر بالعملية التعليمية تقنيــات الــتعلم المتز امن وغير المتز امن.

• اختصـار وقت التعليم مع تقليل التكلفـــة

$$
\text { التعليمية. }
$$

• العملية التعليمية تتم في أي وقت وفـى أي مكان دون نو اجد المعلم و المتعلمـين ولين

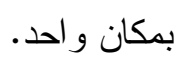

• يمنح المتعلمين الفرصة للتجربة و الخطأ في جو من الخصوصية بمعـزل عـن الآخرين، مما لا يشعر هم بالحرج نتيجة

$$
\text { الخطأ. - اخرين }
$$

• تتو افر مصادر تعلــم متعـددة يمكـن

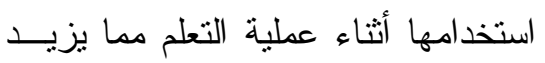

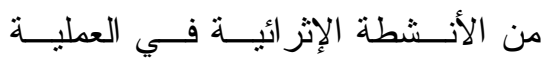

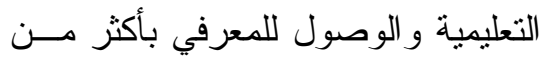

$$
\text { وسيلة. }
$$

• تتو افر خاصية مهمــة بـالتعليم وهـي لعـي العلاقة التفاعلية بين المتعلمين و المعلــم

$$
\text { و المتعلمين بعضهم البعض. }
$$

• يطور من قدرة المتعلمين على استخدام

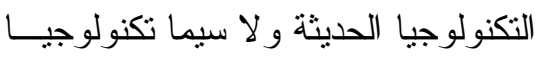

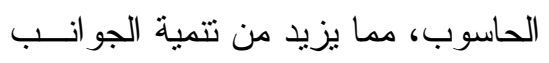
المعرفية و المهارية لاى المتعلمين. • خلق بيئة تدريبية وتعليمية أكثر تـشويقًا و إثارة وتحقَيز اللتعلم و اكتساب المعارف لتهن

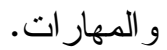

البحث على أبعاد مقياس جودة الحياة المعـد لهذا الغرض ". لأبط

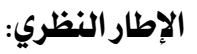
أهميــة الــتعلم باســـتخدام بيئــات الــتـعلم الافتراضية في عمليتي التعليم والتعلم: أولاً: بيئات التعلم الإفتر اضية: مزايا استخدام الفـصول الافتراضــية فــي

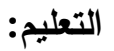

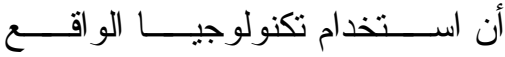
الافتز اضي في العمليــة التعليميــة يـسـاعد المتعلم على(McKinney et-al, 2009) : - استكثاف الأماكن و الاشياء التي يصعب

$$
\begin{aligned}
& \text { الوصول إليها. } \\
& \text {-استكشاف الأشياء الحقيقية دون الاخــلدل } \\
& \text { بمقاييس الحجم و الأبعاد و الزمن. } \\
& \text {-التفاعل مع الأخرين من أمــاكن بعيــدة } \\
& \text { بطرق عير مألوفة. } \\
& \text { - التفاعل مع الكائنات الافتر اضية . }
\end{aligned}
$$

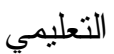

ويلخص كل من :(السيد عبد المولى

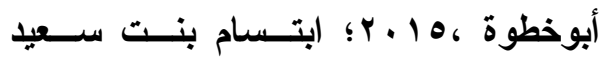

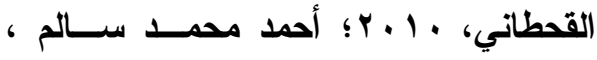

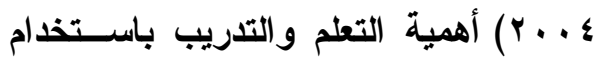
بيئات التعلم الإفتر اضي فيما يلى: 
r- جعل المتعلم يتفاعل تفاعلا إيجابيا مع بيئته المحلية و العالمية r- كسر حاجز الرهبــة فــي اســتخدام التكنولوجيا .

ع - توفير مادة تعليمية متميزة .

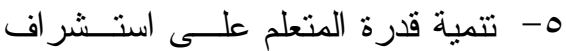
المستقبل - المبن

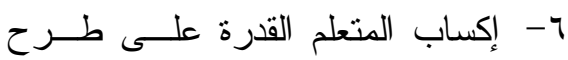

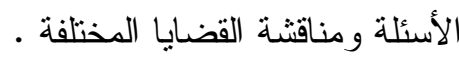
- V - تمكين المتعلم مــن مو اكبـــة التغيــر المستمر للمعارف و المعلومات . ^- تأكيد التوجه نحو الاســقلالية فـي - التعليم • ا-ـتزويد المتعلم بالخبرات المساعدة لـــه في حياته العملية ،وفي التغلب علـى بـى مشكلات وتحديات العصر 1 ا-ليس من الضروري تخصيص الكثير

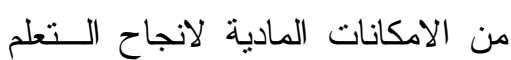

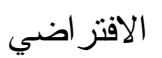
r ا-تتيح المشاركة بالاسئلة والاجوبة من خلال منتديات النقاش وتبادل الرسائل

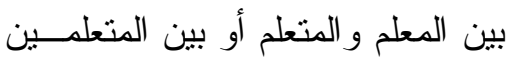
وبعضهم البعض.

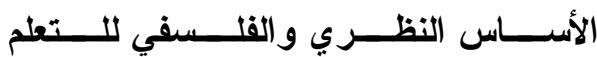
الافتر اضي: يعتمد التعلم الافتراضي على مبــادى

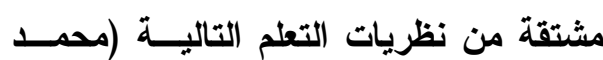

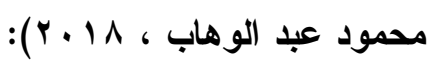

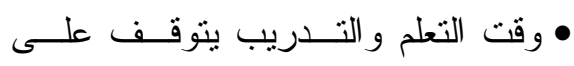

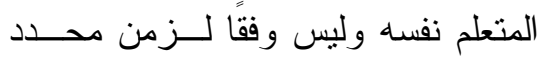

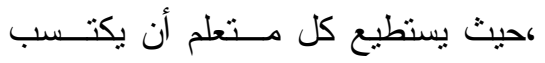

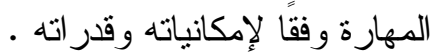

وفي إطار الاهتمام باستخدام الفصول ولهابل

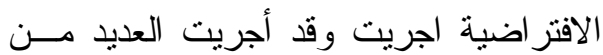

الدراسات و البحوث عن الفصول الافتز اضية

و علاقتها ببعض المتغير ات الأخرى و أكــدت التهن

هذه الدراسات فعالية التعليم و التعلم باستخدام

الفصول الإفتز اضية ، ومن هذه الدر اسات:

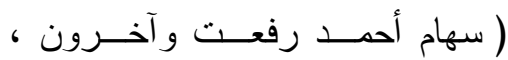

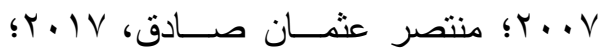

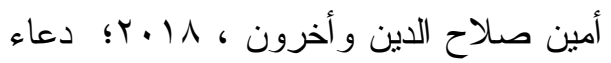

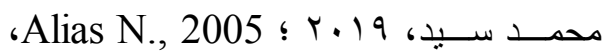
(Harris A, \& Rea A., 2009 أهداف التعليم الافتر اضي : للتعليم الافتز اضي العديد من الأهداف الفئ

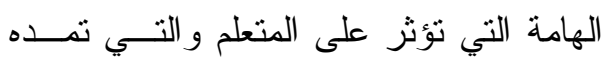

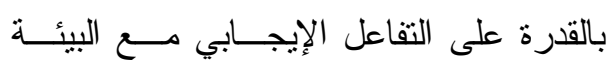
التعليمية كما تمكنه من القدرة على اســتخدام

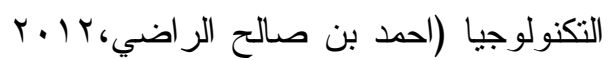
Barbara S., ؛ Ben D., et- al, 2003 ؛ ومن أهم هذه الأهداف ما يلي : 1- تتمية الاتجاهات الإيجابية عند المتعلم

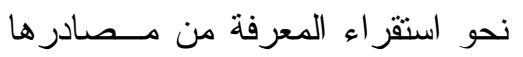
المختلفة . 


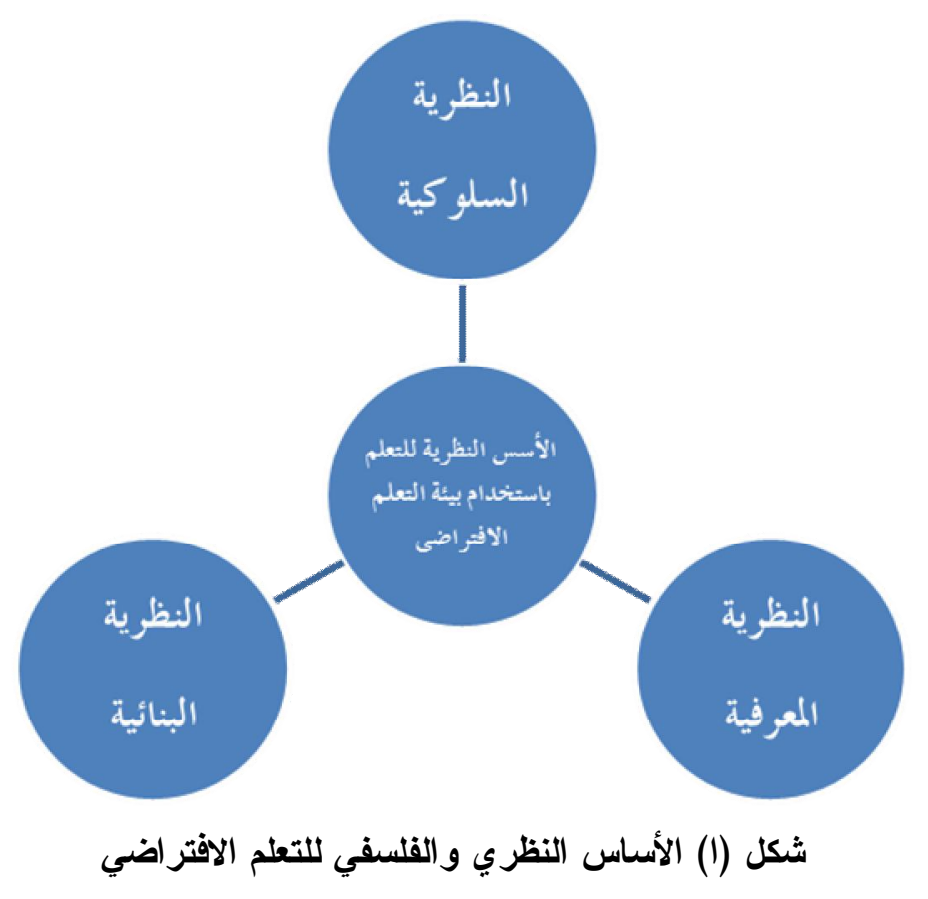

الذاكرة طويلة المدى لدى المتعلم، و استخدام النظرية المعرفية: استر اتيجيات تتيح للمتعلم إدر الك المعلومسـات ولتهات بحيث يمكن انتقال المعلومات مــن الــذاكرة

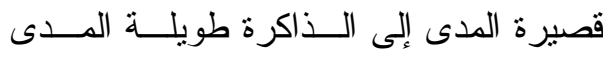

(Modritscher F.,2006) النظرية السلوكية:

يرى العلماء بناء على هذه النظرية أن يرى أصحاب النظرية المعرفيــة أن التعلم يحدث نتيجة اســنقبال المعلومــات

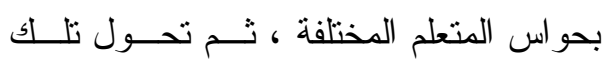

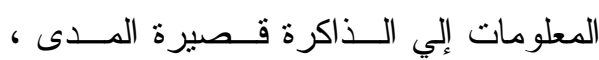
وطويلة المدى عبــر العمليــات المعرفيــة

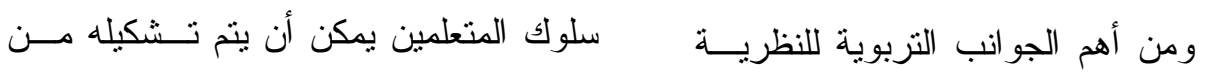

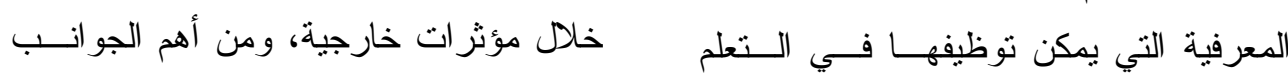

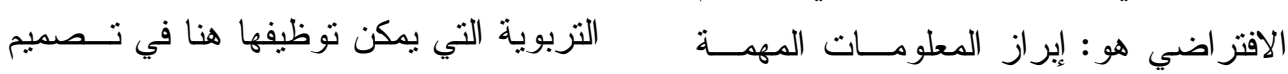

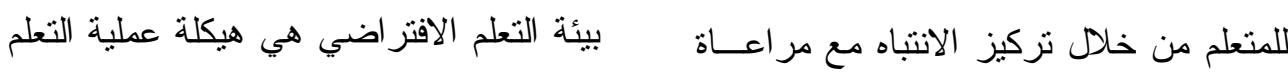

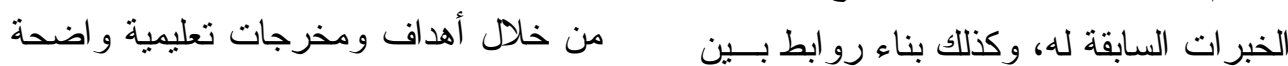
المعلومات الجديدة و المعلومات المخزنة فـي و ومددة مسبقة، و والتدريب و الممارسة عليها، 
Interaction : التفاعل

تتميـز البيئـــة الافتر اضــية بتفاعـلـ

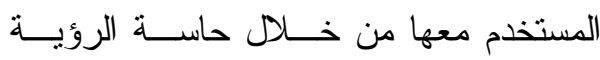

$$
\text { و السمع . }
$$

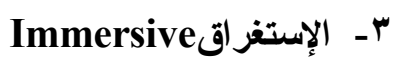

يعني اندماج المستخدم داخــلـل البيئــة

الافتر اضية وشعوره بأنه يتعامل مع العـالم

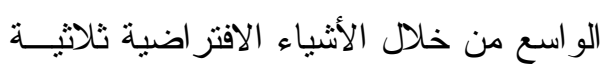

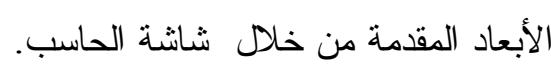

ع - التعاون: Co- Operation

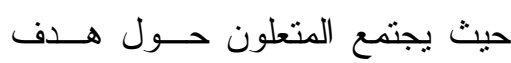

و احد وهو التعامل مع بيئة افتر اضيه خاصة لهئ

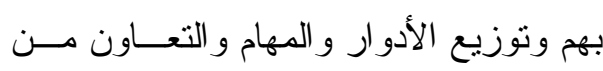
أجل تحقيق أهدافهم .

๑ـ المحاكاة: Simulation

حيث يطلب من المتعلمين التعامل مع

المواقف المختلفة فــي ضــــوء المعطيــات

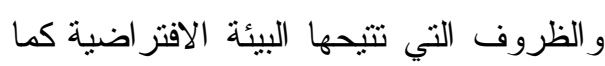

$$
\text { يتم في الواقع. }
$$

بيئات التعلم الافتر اضي

المدرسة أو الجامعة التقليديـة هـيـي

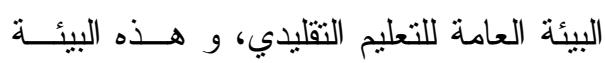

تشتمل بداخلها علي بيئات إدارية وتعليميــة

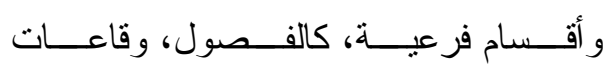

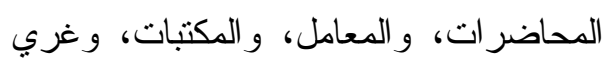

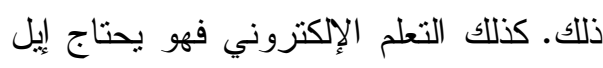

مع تقديم التغذية الر اجعة الفورية مـــع كـلـ

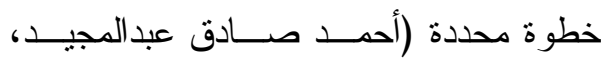
$(r \cdot)$. النظرية البنائية:

بــرى أصــــاب هــــه النظريـــة أن

المتعلمين يبنون معارفهم بناء على ما لــديهم

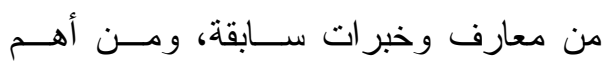

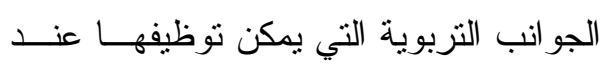

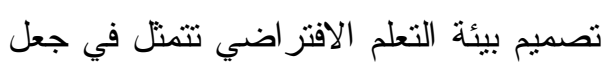

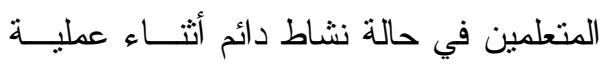
التعلم، وذللك من خلال تطبيق المعلومات في

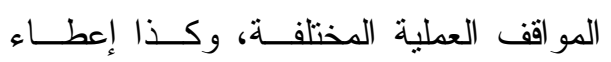

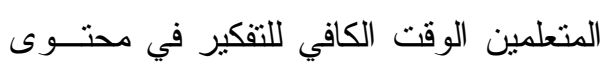
التعلم، و الاهنمام بالأنشطة التفاعليــة ( Ally .(M.,2008

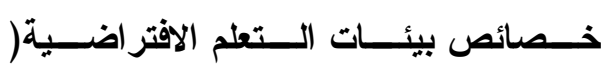
:(Shauna S., 2003

ا - بيئات ثلاثية الأبعـاد - Dimensional

Three :

يتم إعداد البيئة الافتز اضية باستخدام

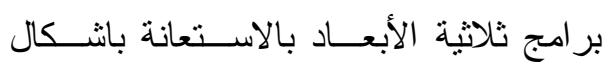

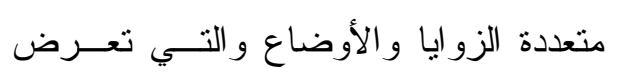

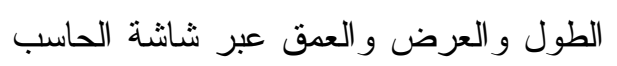

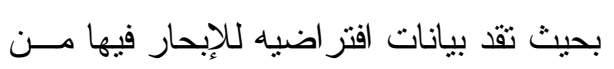

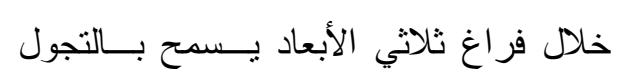
داخلها. 
الخطية ـالرســوم المتحركـــة - الــرو ابط الفائقة - قو اعد البيانــات - أدو ات التفاعـلـل و الاتصال - أدوات عرض المقرر. أنواع بيئات التعلم الافتر اضية:

تتتوع العو الم الافتر اضـــية التعليميـــة

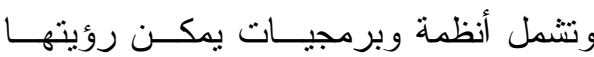

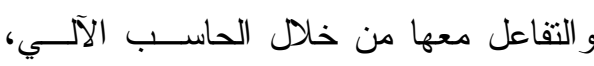
وتتيح تلاك النظم و البر امج للمتعلمين امكانيـــة هولة

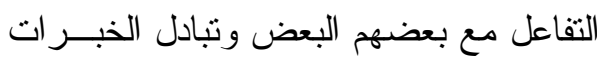

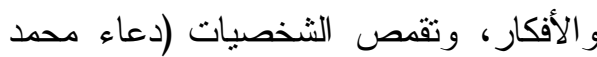

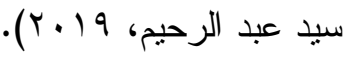
أولاً: الفصول الافتر اضية.

تتعدد مسميات الفصول الافتر اضــية، حيث تُعرف بالفصول الإكترونية، و الفصول

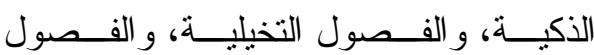
الافتر اضـــية، وفــصول الــشبكة العالميــة

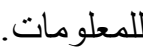

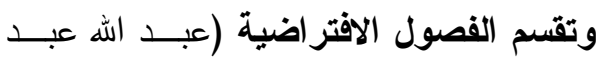

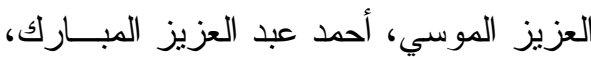

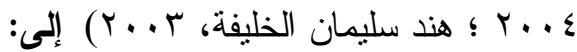
1- الفصول الافتر اضية المتزامنة:.

و هي فصول شبيهة بقاعات الدر اســة

يستخدم فيها المعلم و الطالب أدوات وتثقنيـات

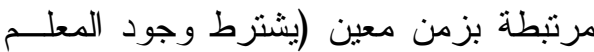
و الطالب في الوقت نفسه دون حدود للمكان)

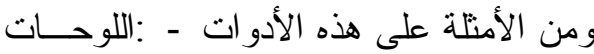

نظام بيئة افتر اضيه عامة، تـشتنمل بــــاخلها علي بيانــات إداريــة و تعليميــة و أقـــسام

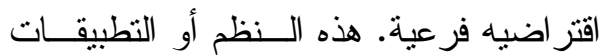

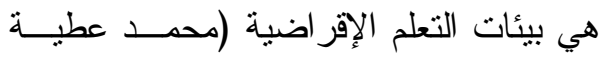

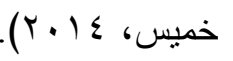

وتتتوع عبئات التعلم الإفتر اضية وفقــــا

لتعدد أغر اضها و التقنيات المـستخدمة فـي تصميمها لذا يمكن تقسيمها إلى:

وتنقسم هذه البيئات الافتراضية إلى قسمين

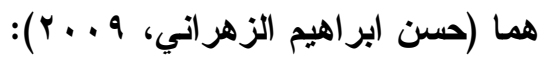

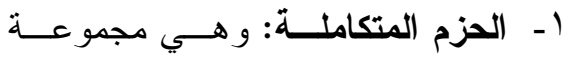
متكاملة مسـن الأدوات الغيـر قابلـــة

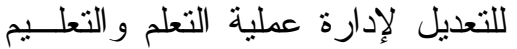
ويقـسمها محمـــد عطيــة خمــيس

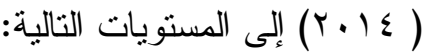
- نظام إدارة المحتوي" "CMS" نظام إدارة المقرر - نظام إدارة التعلم:LMS r- الحزم المنفردة: وفى هذه النوعية من

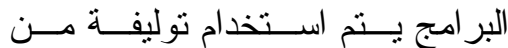

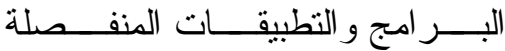

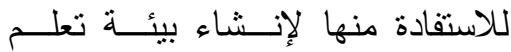

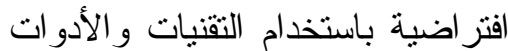

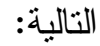

النصوص المكتوبــة - الــصوت الصور الثابتة - الصور المتحركة - الرسوم 
وإجر اء التجارب عليها في و اقع يشبه الواقع

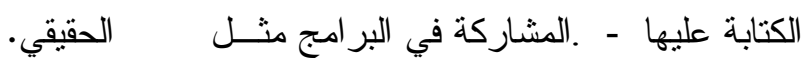

البرامج التي تساعد المعلم في إنشاء الفصل

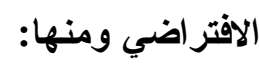

BlackBoard

$$
\text { • - مبرنامج }
$$

• برنـــامـج المقـــررات الدراســـية

Moodle

claroline برنامج

WebCT برنامج

Schoology برنامج

م برنامج wiziQ

واســـتخدمت الباحثـــة برنــــامتج

Schoology

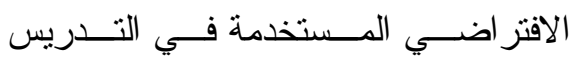

للمجمو عة التجريبية.

برنامج الفصول الافتر اضية Schoology:

برنامج Schoology هو نظام ادارة

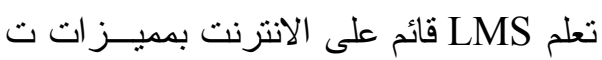

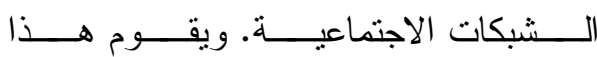

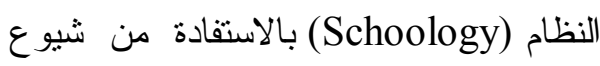

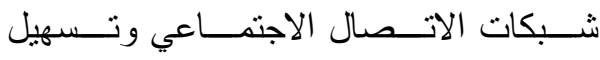

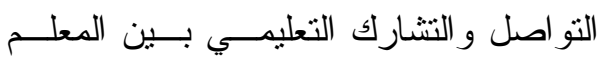

و الطلاب وأولياء الأمور لتحقيــق العمليــة

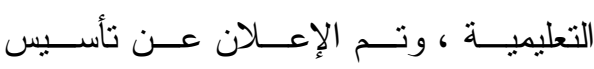

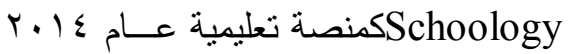

$$
\text { بو لاية كولور ادو الأمريكية. }
$$

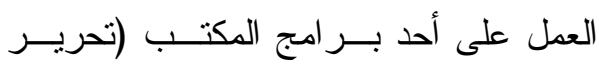

). - النصوص - عروض - قو اعد البيانـات

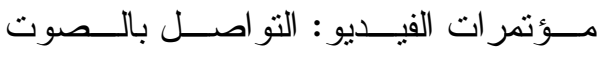
و الصورة و النص بين المعلم وطلابه وبـين بين الطلاب بعضهم البعض - ـمؤتمر ات الصوت ولهن التو اصل بالصوت و النص بين المعلم وطلابه وبين الطلاب بعــهم الــبعض - .غــرف

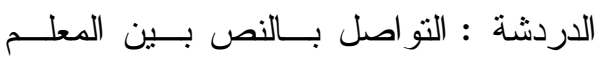
وطلابه وبين الطلاب أنفسهر.

r -الفصول الافتراضية غير المتزامنة: وهي الفصول التي لا تتقيد بزمان أو مكان لذا فهي تستخدم برمجيات وتقنيات غير تزامنية أي لا يشترط وجود المعلم و الطالب لهن في نفس الزمن و هذا ما يعرف بالتعلم الذاتي

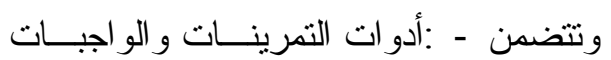

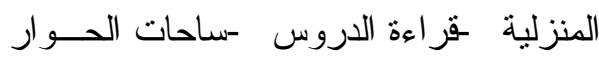
و النقاش غير المباشرة ـقائمة المراســلات بين المعلم وطلابه -قائمة الدرجات -إرسال الأعمال و المشاريع إلى المعلم.

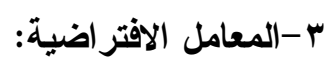

وهي معامل تحاكى المعامل التقليديــة

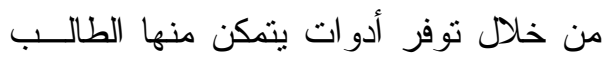
من تحريكها بو اسطة لمس شاشة الكمبيــونر 


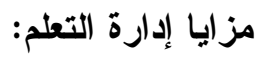

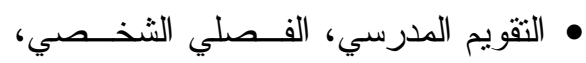

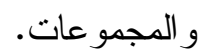

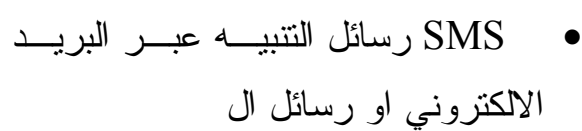

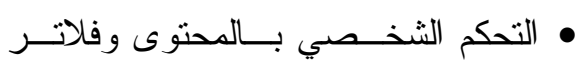

$$
\begin{aligned}
& \text { الكلمات }
\end{aligned}
$$

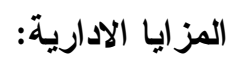

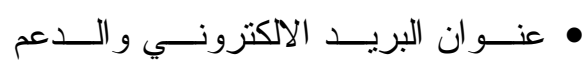

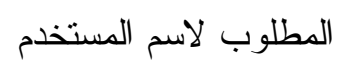

$$
\begin{aligned}
& \text { • الدخول الموحد للموقع حيث لا يحتــاج }
\end{aligned}
$$

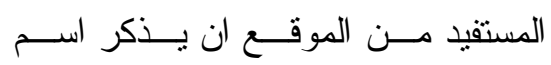

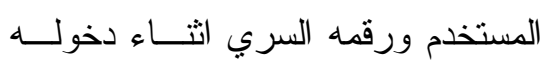

$$
\begin{aligned}
& \text { للأنظمة الفرعية داخل الموقع بل يكفــل }
\end{aligned}
$$

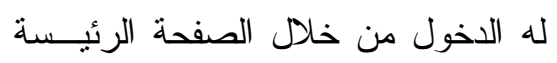

$$
\begin{aligned}
& \text { حرية الابحار خلال الموقع. } \\
& \text { • ارسال و استقبال المقررات، المستخدمون } \\
& \text { و الدرجات. }
\end{aligned}
$$

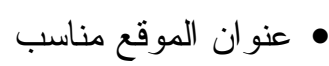

$$
\begin{aligned}
& \text { • امكانية دخول اولياء امور الطلاب. } \\
& \text { ويوضح شـــكل (r) و اجهــة برنــامج } \\
& \text { Schoology } \\
& \text { وتحليل المحتوى منابعه دول و } \\
& \text { التنفيذ } \\
& \text { • المدونات و الصفحات الشخصية }
\end{aligned}
$$




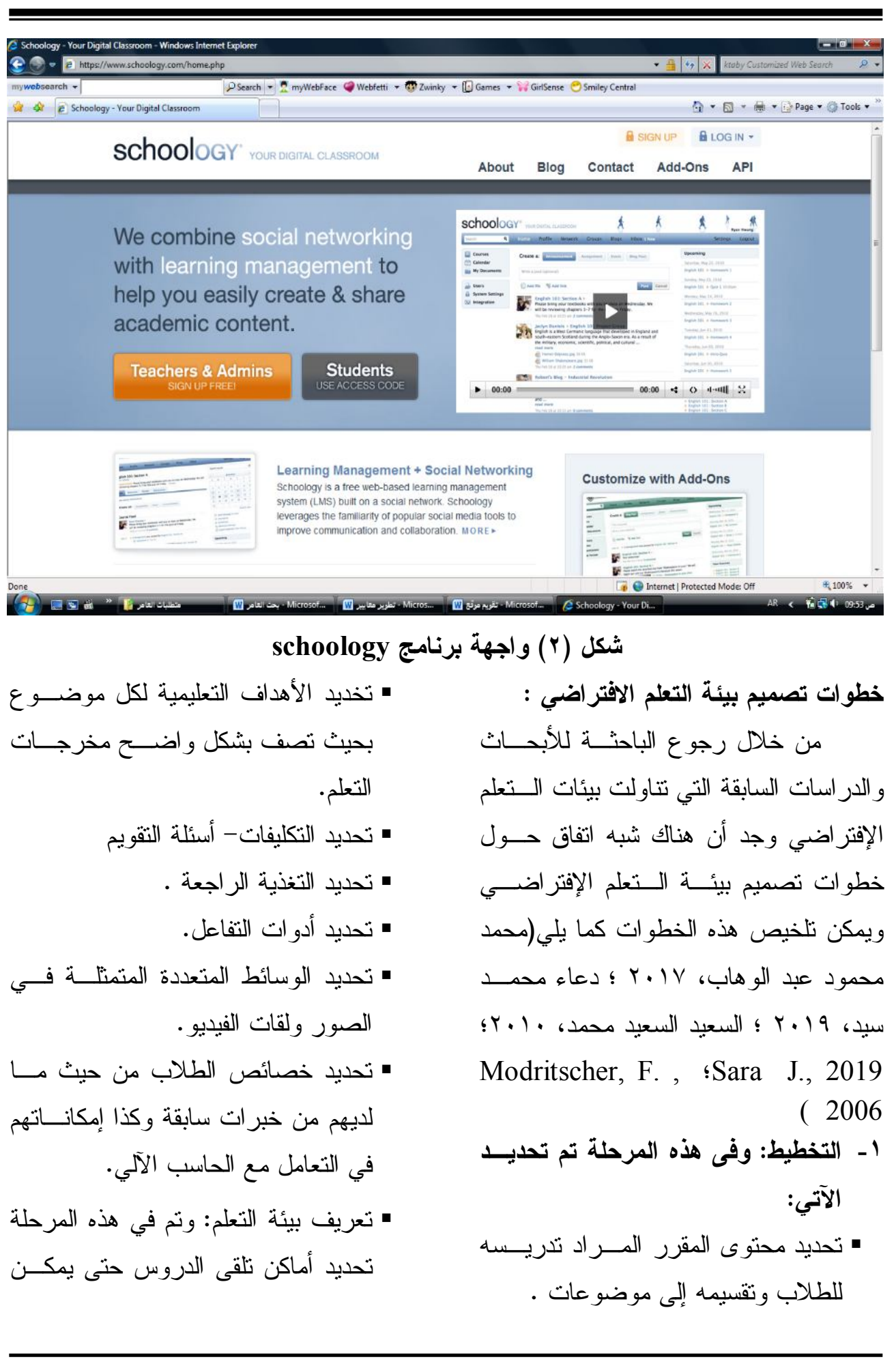




$$
\begin{aligned}
& \text { - قامت الباحثنة بعقد لقـاء تــدريبي مــع }
\end{aligned}
$$

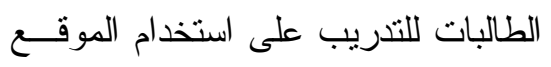

$$
\begin{aligned}
& \text { في در اسة المقرر • }
\end{aligned}
$$$$
\text { التعرف على الإمكانات المتاحسـة لــــى }
$$

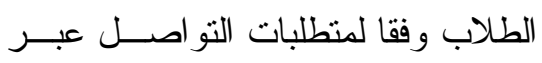$$
\text { الفصول الافتر اضية. }
$$

• تحديد جدول زمنى لجلــسات الفـصول

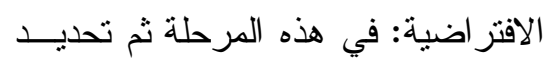

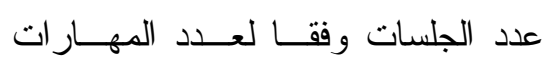

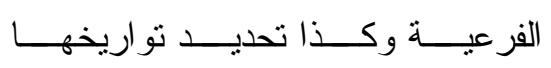

$$
\text { ومو اعبد ها. }
$$

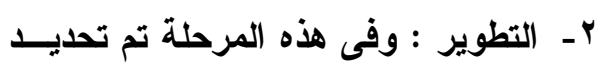

تم في هذه المرحلة قياس مدى فاعلية

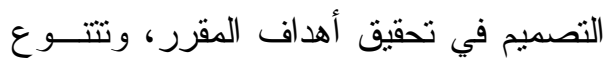
• تحديد محتوى الموضو عات .

أساليب التقويم المستخدمة في بيئــة الــنعلم

الافتز اضي فمنها تكليفات و أســئلة نقويميــة فئة

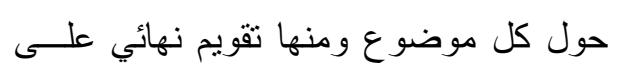

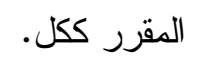

ويوضح شكل (r) خطو ات تـصميم

• إنشاء جلسات الفصول الافتر اضية وفقا

$$
\text { للجدول الزمنى للجلسات. }
$$

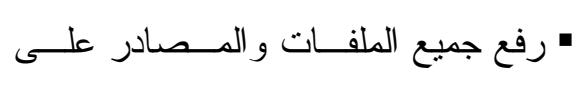

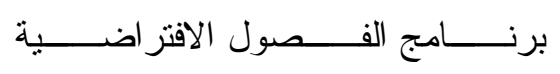

\section{.Schoology}

بيئة التعلم الافتز اضية (محمد محمــود عبــد

r- مرحلة التنفيذ :

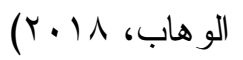

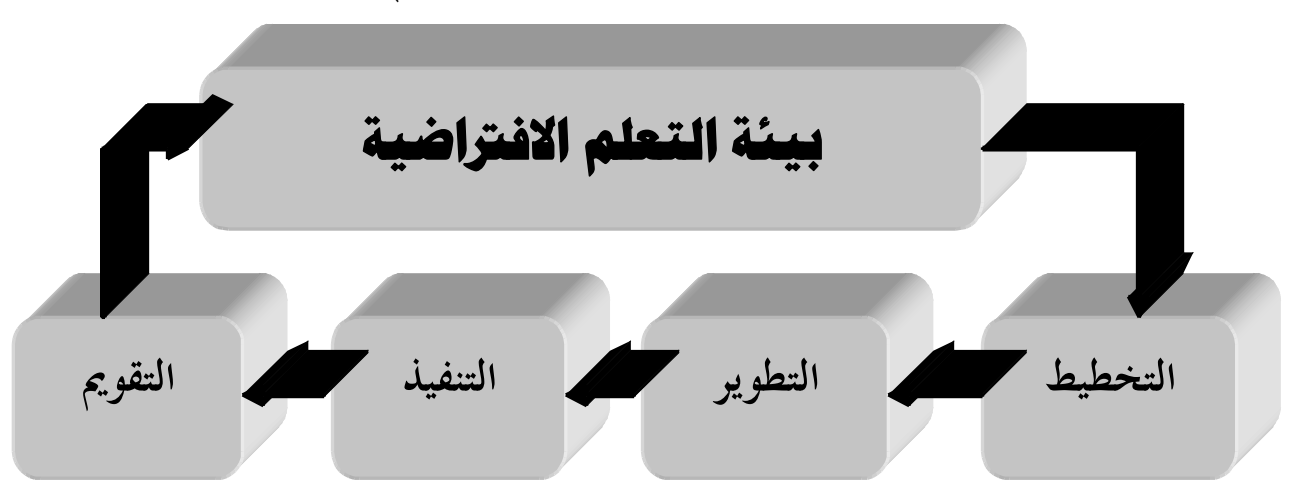

شكل (r) خطوات تصميم بيئة التعلم الافتراضية 


\section{ثانياً: جودة الحياة.}

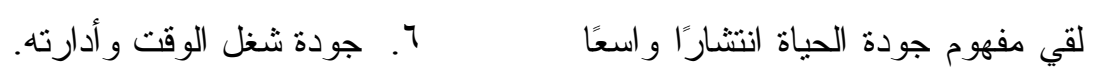

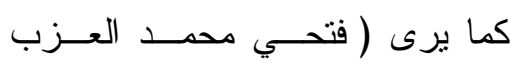

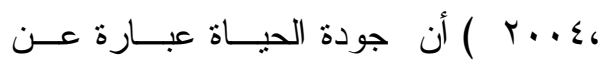
مفهوم يثير إلى ستة أبعاد أساسية ويمكـنـ قياس جودة الحياة لدى الفرد من خلالها وهي لئي

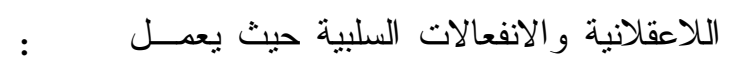

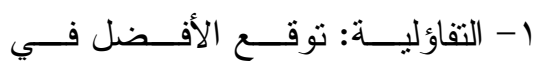

$$
\text { المستقبل. }
$$

ץ- تقدير الذات: وتشير إلى تــصورات

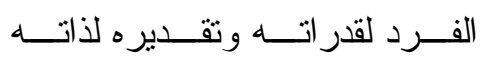

$$
\text { وكفاءته. }
$$

r- الرضا عن المهنة: أي الرضا عــن

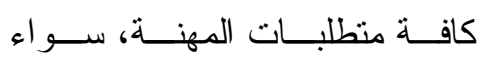

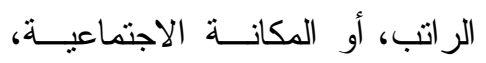

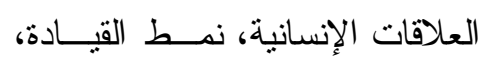

غان...................

ع- التوقعات المستقبلية: وهى مجموعة

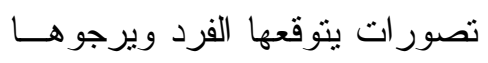

$$
\text { في المسنقبل. }
$$

0- الممارسات الدينية: هي تشمل كافة

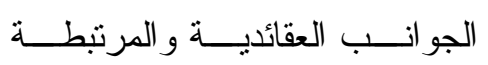

$$
\text { بالنو احي الروحانية }
$$

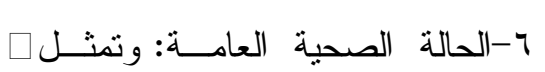

الجانــب الــصحي بــشكل عـام

و السلامة البدنية
في شتى المجالات ، وذللك استجابة لأهميــة النظرة الإيجابية في الحياة ، ويعبر مصطلح

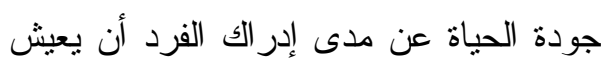
حياة جيدة من وجهة نظرة خالية من الأفكار

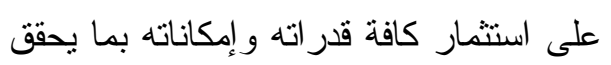

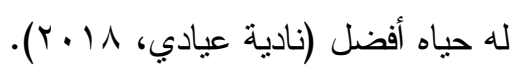

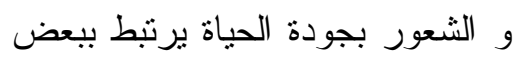

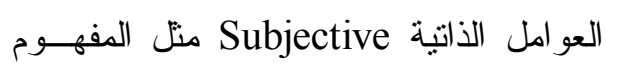

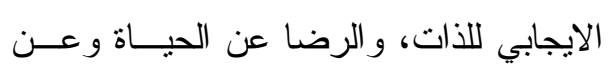

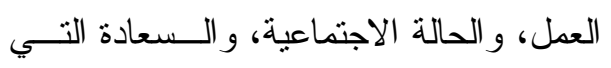

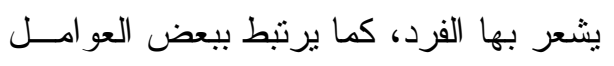

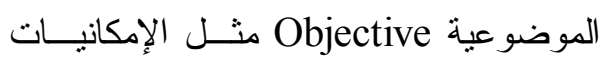

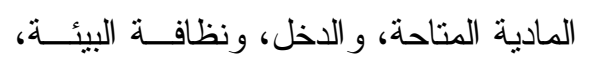
و الحالة الصحية، و الحالة السكنية و الوظيفــة ولئة ولئة

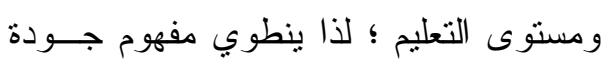
الحياة على عدة أبعاد هي (محمود عبد الحليم

$$
\begin{aligned}
& \text { منسي و علي مهدي كاظم، ج ج . ب): } \\
& \text { 1. . جودة الصحة العامة } \\
& \text { r. . .جودة الحياة الأسرية و الاجتماعية } \\
& \text { بـ. جودة التعلميــة و الدر اسة } \\
& \text { ع. . جودة العو اطف و الجانب الوجداني } \\
& \text { للمفرد . لمودة المو }
\end{aligned}
$$

๑. جودة الصحة النفسية . 
الحياة ؛ لذا فاختلاف درجــة أو شـــة هــــه

المحددات يقيم مدى جودة الحياة لدى الفرد.

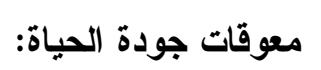

إذا نظرنا للحياة بشكل عام سنجد أنها

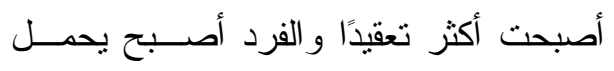
على كاهله الكثير من الضغوط و التحـديات

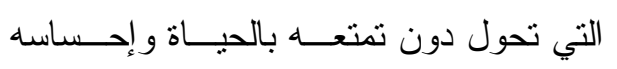

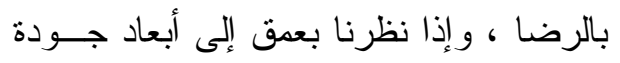

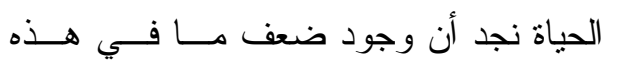
الأبعاد يشكل معوقًا عن تحقيق جودة الحياة.

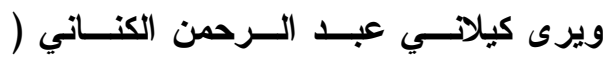

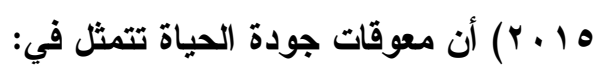

$$
\begin{aligned}
& \text { ا . . ضغوط أحداث الحياة. } \\
& \text { r. فقدان الثعور بمعني الحياة. } \\
& \text { r. ق قلة الوازع الديني. }
\end{aligned}
$$

ع. عدم توفير سبل الرعاية الـصحية

$$
\text { الكاملة للأفر اد. }
$$

0. افتقاد الكثير من الأفــراد للـــكاء

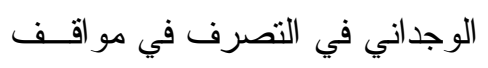

الحياة المختلفة.

تحسين جودة الحيــاة ودر اســـة الاقتــصاد

$$
\text { المنزلي: }
$$

الاقتصـاد المنزلـــي مر ادفًا لعلـــوم

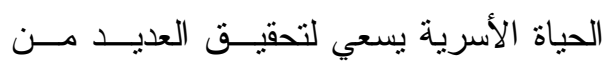

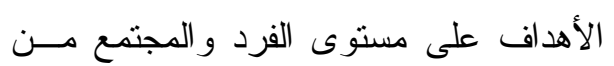

ويؤكد (محمد السعيد أبــو حــلاوة،

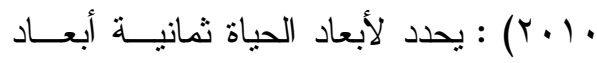

يمكن في ضوئها تقييم مدى جـــودة الحيــاة

$$
\text { للفرد وهي: لبكن وي صون }
$$

- السلامة البدنية و التكامل البدني العام.

$$
\text { - الثعور بالسلامة و الأمن. }
$$

- الثعور بالقيمة و الجدارة الشخصية.

- الحياة المنظمة المقننة.

- الإحساس بالانتماء للآخرين.

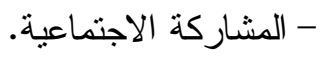

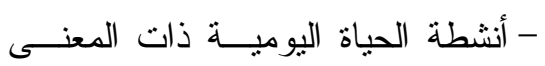

$$
\text { الهادفة. }
$$

- الرضا و السعادة الداخلية.

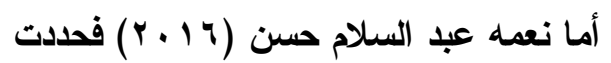

أبعاد جودة الحياة كما يلي:

إدارة الوقت وشغل أوقات الفراغ

$$
\text { • الحياة الأكاديمية }
$$

و العاقات الاجتماعية الأسرية

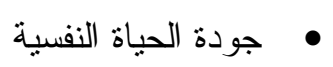

وتزى الباحثة أنه بالرغم من اختلاف

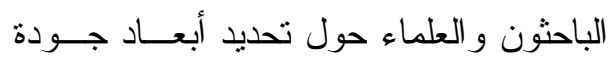

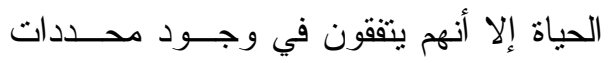

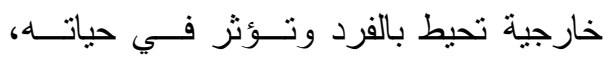

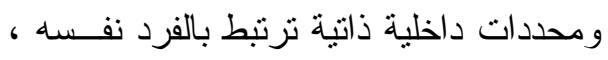
و هذه المحددات تشكل في مجملها أبعاد جودة 
ومن الدراســات الـسـابقة التــي تناولــت

الاقتصاد المنزلي وجودة الحياة :

دراسة (غادة محمد حسني، 7 (ب)

التي هدفت إلى دراسة استر اتيجيات النجـــاح

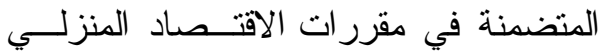

بالمرحلة الثانوية و علاقتها بجودة الحياة.

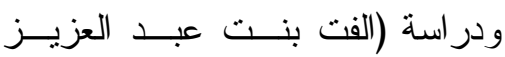

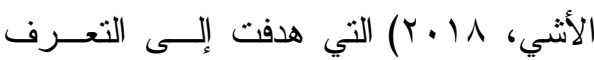

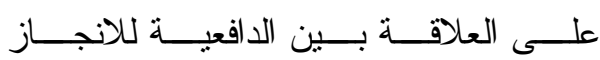

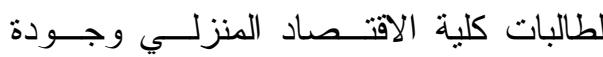

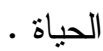

ودر اسة ( ايمــان محمــد رشــوان،

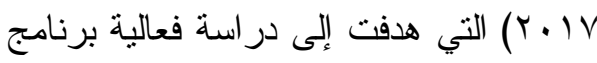

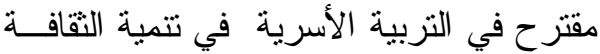
الأسرية وجودة الحياة.

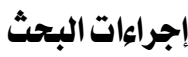

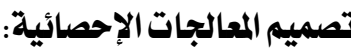

قامت الباحثَــة بتــصميم المعالجــات

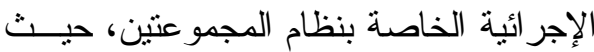
تم تطبيق أدوات البحث قبليًا للتأكد من تكافؤ

المجموعتين، ثم التعليم وفقا لاستخدام بيئــة

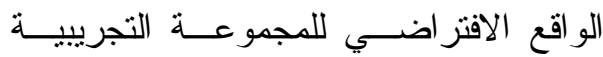
و الطريقة التقليدية للمجموعة الضابطة ثم تــم

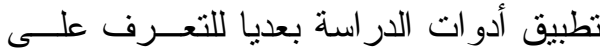

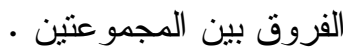

خلا عدة مجالات تجمـع بــين النظريــة

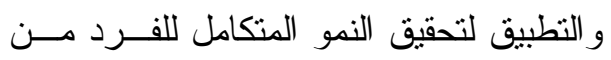
جميع النو احي ·

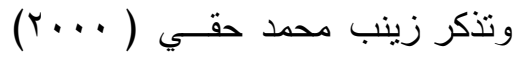

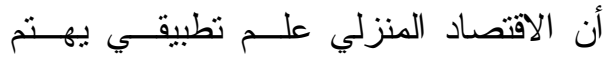
بدر اسة علاقة الانسان بالبيئة المحيطة ويهنم بتتمية الفــرد و الأســـرة ويلبــي احتياجــات · المجتمع

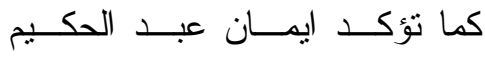

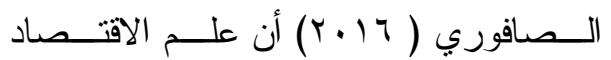
المنزلي من العلوم التي تدعم التتمية البشرية

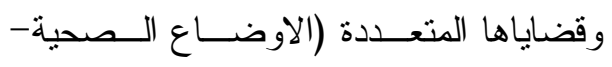

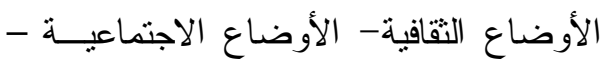

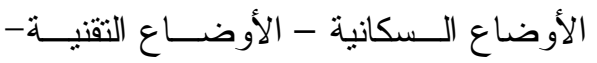

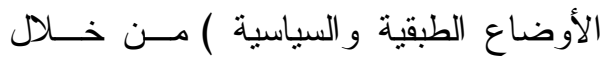
مجالاته الخمسة الرئيسة التي تــــنبط بحيـــاة الأسرة و المجتمع وتسعى إلى تتمية الإنسان . وتنشير (Helen A., 2011) إسـى

أهمية دور الاقتصاد المنزلى فـي تحسسين جودة الحياة للأفر اد والأسـر و المجنمعـات لتحقيق عيشة أفضل في مجتمع دائم التغير. وبذلك يمكن القول بأن دراسة مادة الاقتصاد المنزلي (التزبية الأسرية) تسهم في بـان درنه

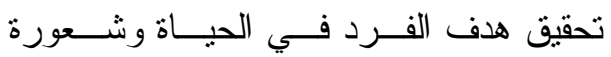
بالرضا و السعادة وتلبية احتياجاته المتعـددة وتحسين جودة الحياة لدى الفرد. 


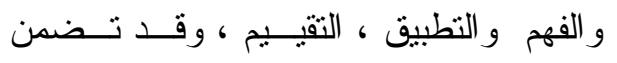

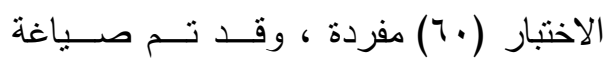
مفردات الاختبار بشكل إلكتروني، وروعـي وني

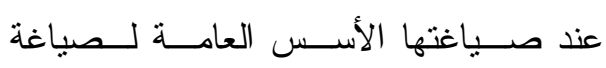

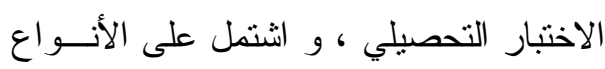
التالية:

القسم الأول:أسئلة الصو اب و الخطأ. القسم الثاني: أسئلة ملء الفر اغات. القسم الثالث: أسئلة الاختيار من متعدد. القسم الر ابع: أسئلة المو اقف. وضع تعليمات الاختبار:

حرصت الباحثــة علــى أن تكــون

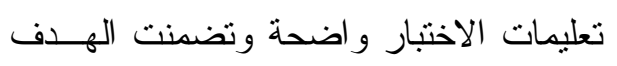
من الاختبار ، وتعريف الطالبة بكيفية الإجابة

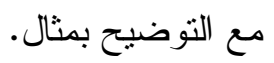
صدق الاختبار : صوتع قامت الباحثة بــالتحقق مــن صــدق

الاختبار من خلال عرض الصورة الأوليـــة للاختبار التحصيلي على عدد من المحكمين

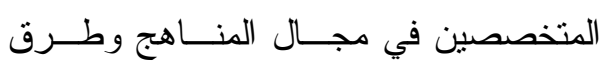

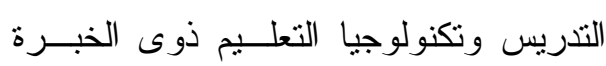
و التخصص في تكنولوجيا؛ للتأكد من صــدق دوث

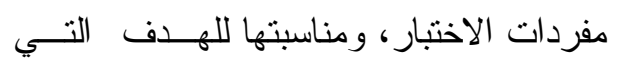

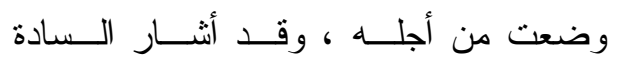
المحكمون إلى بعض التعديلات منل:

$$
\text { المواد التعليمية و أدوات البحث: }
$$

1- مقرر الاقتصاد المنزلي باستخدام بئـــة

$$
\text { تعلم افتر اضي: }
$$

قامت الباحثة بتـــميم بيأسـة تعلـــم

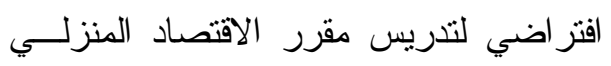

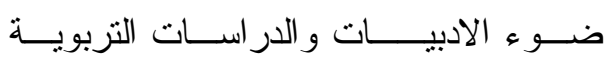
السابقة التي تتاولت التعلم الإلكتروني وبيئات

$$
\text { التعلم الافتر اضي. }
$$

وتضمن الفصل الافتراضي ما يلي : 1- صفحة عنوان المحاضرة r- بفحة الأهداف r- - صفحة المحتوى ع- ـفحة أدوات التفاعل ○ـ الأنشطة و التنكليفات

ד- عروض فيديو وصفحات ويب وصور V- V

r- اختبار التحصيل المعرفي الاكتروني • الههف من الاختبار:

هدف الاختبار الإلكتروني التحــصيلي

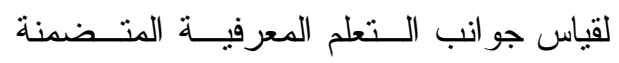

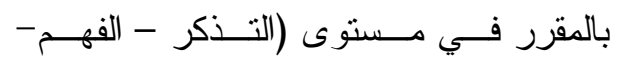
النطبيق - التقييم). الصورة المبئية للاختبار :

تم وضع أسئلة الاختبار وفقًا لثلاتــة

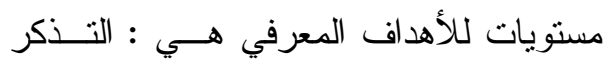


معامل الصعوبة: يقـصد بــه نـسبة

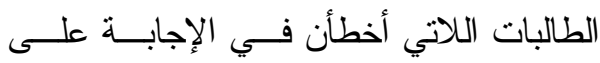

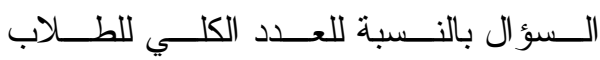

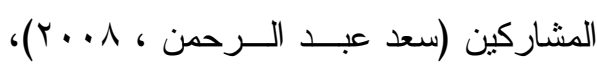

وتز اوحت معساملات الــصعوبة لمفــردات

الاختبار بين • ــ- V \% و هي نسبة مقبولة،

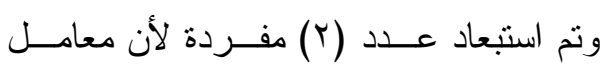

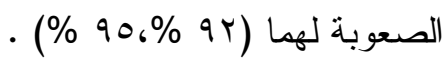

معامل التمبيز: ونقصد بــه : قيــاس

مدي قدرة الاختبار على التمبيز بين التلاميذ

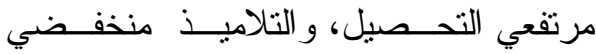
التحصيل (سعد عبد الرحمن ، 1... ب)، تـم ايجاد معامل القوة التمبيزية للبنود الاختبـــار،

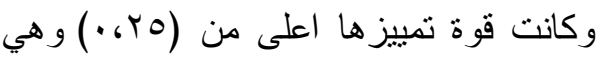

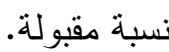

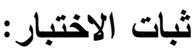

قامت الباحــث بالتأكــــــــن ثبــات الاختبار من خلال تطبيــق الاختبــار علـى

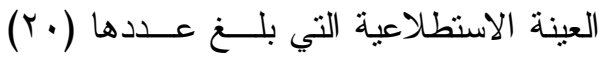
طالبة ، وقد نم اســتخدام معادلـــة التجزئســة

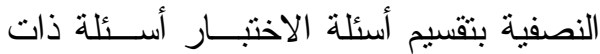

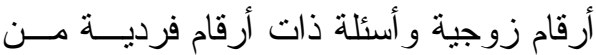

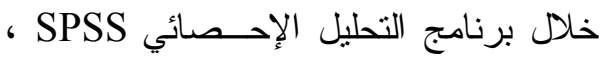

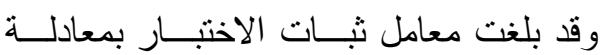

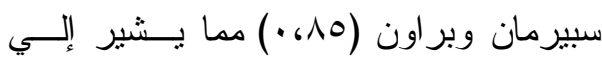
تمتع الاختبار بدرجة ثبات عالية.
- إعــادة صـــاغة بعــض مفــردات

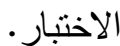
- استبعاد بعض المفردات .

وقد قامت الباحثة بإجر اء ما أثنار إليه

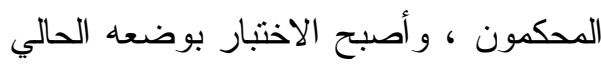

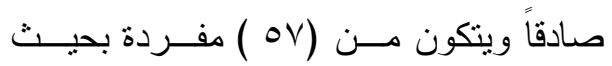

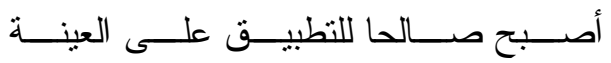
الاستطلاعية لحسـاب معساملات الـسـهولة و التميزية لأسئلة الاختبار ، وحساب معامـلـل الثبات و الزمن المناسب للإجابة عن أسـئلة

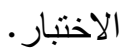

حساب معامل الصعوبة و السهولة و التميـز

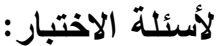

بعد تطبيــق الاختبــار علــى عينــة

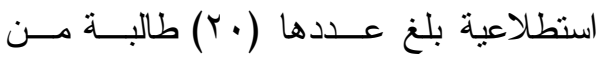

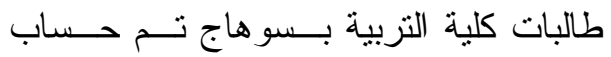
معاملات الصعوبة و الصعوبة و التمبز لأسئلة

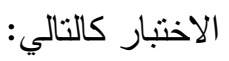
معامل السهولة: يقـصد بــهـ نـسبة

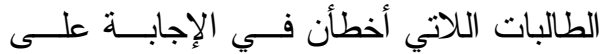

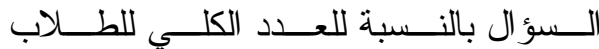
المشاركين (احمد سليمان عودة ، فتحي حسن بالن

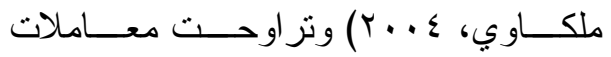

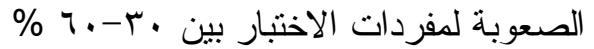
و هي نسبة مقبولة . 
إعداد جدول المواصفات للاختبار:

الصورة النهائية للاختبار:

قامـــت الباحـــث بإعــــداد جــــدول

بعد حساب معامل الصدق لاختبــار

المواصفات للاختبار الإلكتروني التحـصبيلي

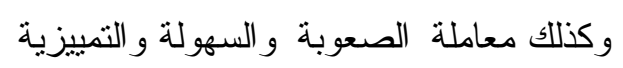

في ضو ء الأهداف العامة للمحتوى العلمـي لإني

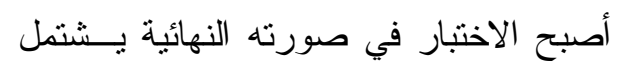
للمقرر الذي تدرسه الطالبات ، كما تم تحديد الاهدي

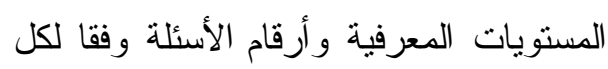
على (00) مفردة، و الدرجة العظمى (00)

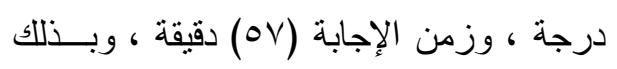

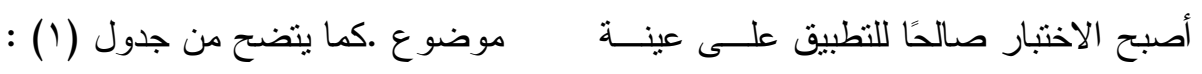
البحث.

جدول (1) مواصفات اختبار التحصيل المعرفي

\begin{tabular}{|c|c|c|c|c|c|c|c|}
\hline المنبي & المجموع & التقييم & التطبيق & الفهم & التذكر & العنوفية & المحاضرة \\
\hline$\% 1 r$ & $\checkmark$ & r & 1 & r & 1 & 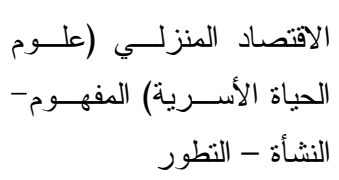 & الأولى ال \\
\hline$\% 10$ & $\wedge$ & r & r & r & 1 & الأسرة و التحديات العالمية & الثاتية \\
\hline$\% 17$ & 9 & r & . & r & r & مجالات الاقتصاد المنزلي & الثالثة \\
\hline$\% 10$ & $\wedge$ & r & r & r & . & العملية الإدارية & الرابعة \\
\hline$\% 1 r$ & $v$ & r & r & 1 & r & الموالموارد الأسرية البشرية & الخامسة \\
\hline$\% 11$ & 7 & $\varepsilon$ & 1 & 1 & . & تابع الموارد الأسرية & السادسة \\
\hline$\% \backslash \vee$ & 1. & r & r & $\varepsilon$ & . & الاستهلاكيلاكي وتتميــة الــوعي & الثامنة \\
\hline$\% 1 \ldots$ & 00 & 11 & Ir & 11 & $v$ & & المجموع الك \\
\hline
\end{tabular}




\section{مقياس جودة الحياة :}

تم الإستعانة في البحث الحالي بمقياس الحياة الأسرية والإجتماعية، جــودة التعلــيم

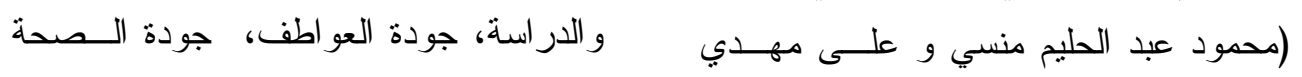

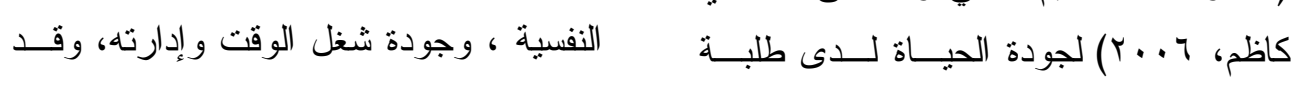

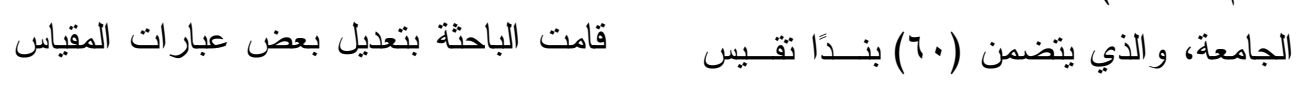

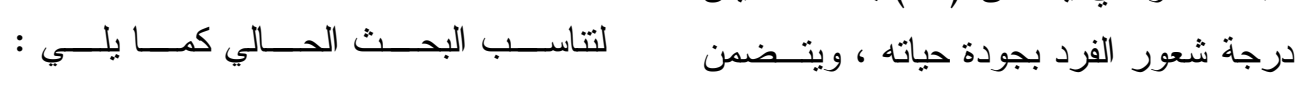

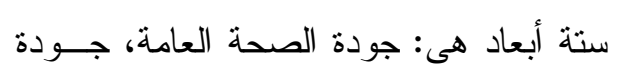

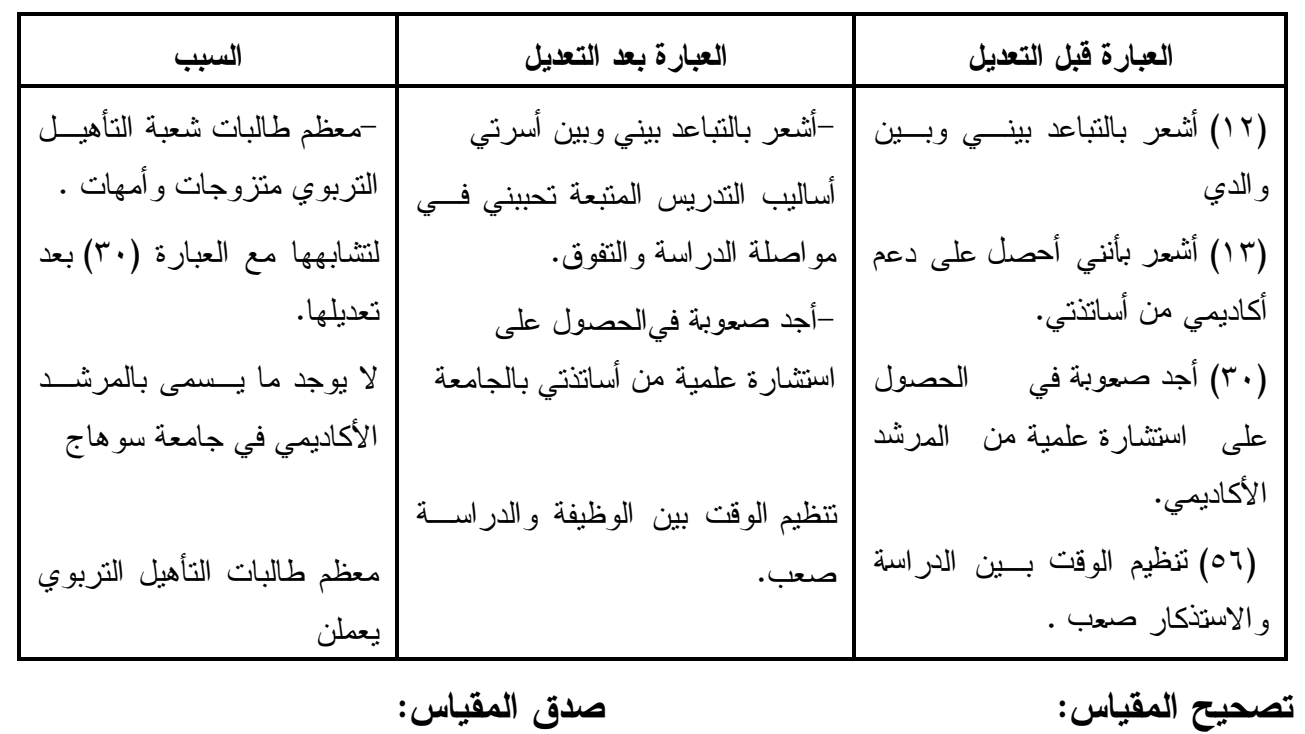

تم حساب صــدق المحتــوى للمقيــاس تكون كل محور من خمسسة عبـار ات

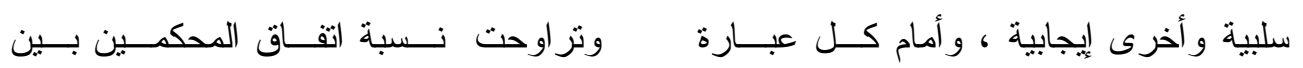

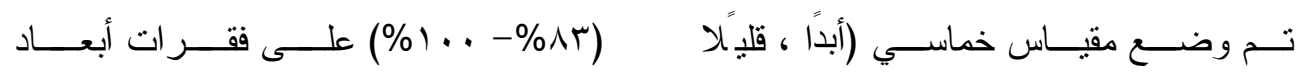

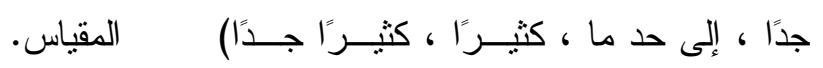

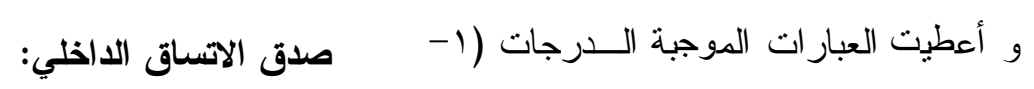

تم حساب معامل الارنباط بين كل عبارة

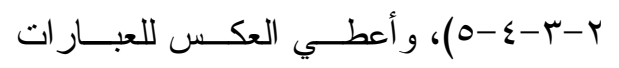

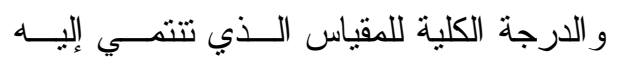


عقد لقاء آخر للتطبيــق القبلـــي لأدوات البحث على المجمو عتين للتأكد من تكافؤ

$$
\text { المجمو عتنين. }
$$

التدريس بالطريقة التقليدية لطالبـات

$$
\text { مجموعة البحث الضابطة. }
$$

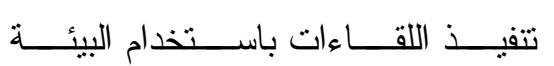

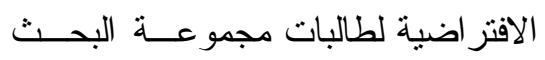

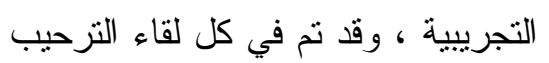

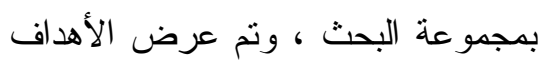

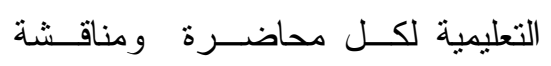

الطلاب حــول المعــارف و المهــار ات

$$
\text { المتضمنة بكل لقاء . }
$$

• بعد الانتهاء من نتفيــذ التطبيــق علــى

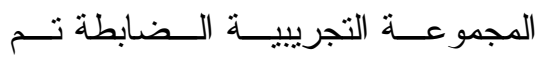

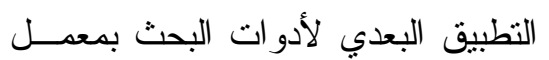

الحاسب الآلي بكلية التربية بسو هاج.

نتائج البحث ومناقشتها:

فيما يلي عرضاً لنتائج البحث وتفسيرها: ا - الإجابة عن الـسؤال الأول واختبـار

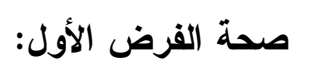
قد نص السؤال الأول للبحث على:

"ما أثز استخدام بيئة تعلم افتر اضــية

قائمة على الفصول الإفتر اضية فــي تتميــة التحصيل المعرفي لــدى طالبــات برنـــامج

التأهيل التزبوي بكلية التربية بسوهاج؟ "

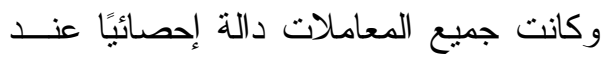
مستوى $\geq 0$ ثبات المقياس:

تم حساب معامل ألفا كرونباخ لــدرجات أبعاد عبار ات أبعاد المقياس الستة وتزاولت اوحتبان

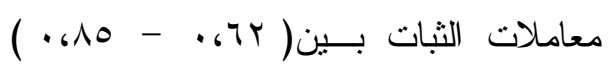
وللمقياس ككل (19، •) مما يدل على تمتعه بدرجة ثبات عالية. تتفيذ تجربة البحث: تم تنفيذ تجربــة البحــث خــلال الفـــل

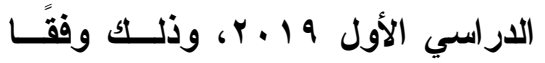
للخطوات الآتية: - ل الاول

عقد لقاء تمهيدي مع الطالبــات عينــة البحث و تقـسمهز إلـى مجمـــوعتين إحداهما مجموعة ضابطة سيتم التدريس

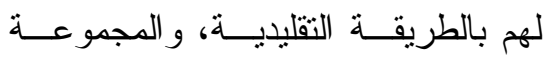

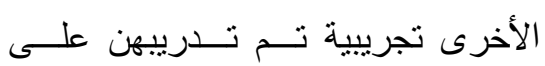
استخدام بيئة التعلم الافتز اضية باستخدام المنصة التعليمية Schoology ، وذلك لكالك

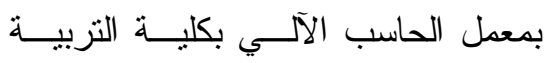

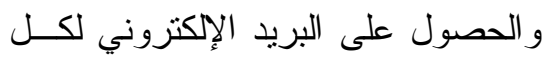
طالب لكي يتم إرسال روابط الفــصول الفيد

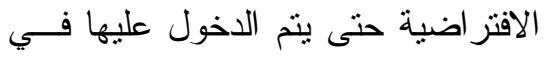

$$
\text { الوقت المحدد. }
$$


الافنز اضي وطالبات المجموعــة الــضابطة

$$
\text { ونص القرض الأول على: }
$$

" توجد فروق ذات دلالة إحصائية عند اللاتي درسن بالطريقة التقليدي."

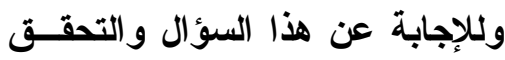

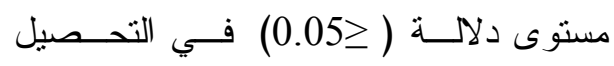

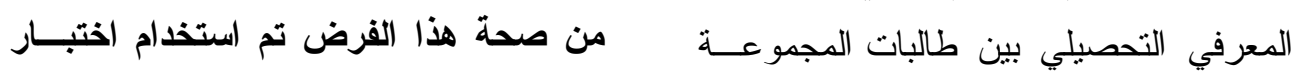

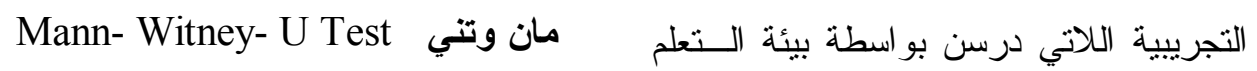

جدول (r )

نتائج تطبيق اختبار مان ويتنى لمعرفة الفروق بين متوسطي نتائج طلاب المجموعة التجريبية و الضابطة في اختبار التحصيل المعرفي

\begin{tabular}{|c|c|c|c|c|}
\hline مستوى الدلالة & مان ويتتى & المتوسط & العدد & المجموعة \\
\hline \multirow{2}{*}{$\cdots$} & \multirow{2}{*}{$\cdot, 0 \ldots$} & I & $r V$ & ضابطة \\
\hline & & $\{., 91$ & TV & تجريبية \\
\hline
\end{tabular}

المنزلي باستخدام بيئة الــتـلم الافتر اضــية

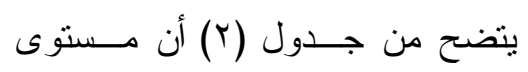

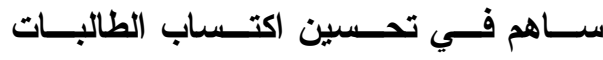

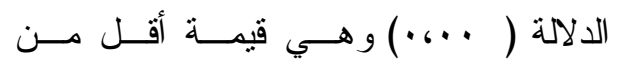
للمعلومات و المفاهيم والحقائق المتــضمنة

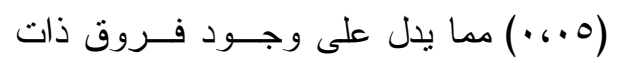
بالمقرر مقارنة بنظيراتهن اللاهــي درســن دلالة إحصائية في اختبار التحصيل المعرفي ولي بالطريقة التقليدية.

وتتفق مع نتيجة البحث الحالي نتيجة بين منوسطي درجات طالبــات المجموعــة

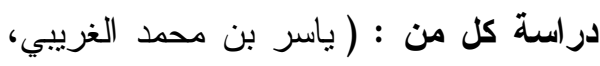

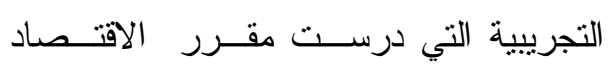
(Bhukuvhani Sana,2012، (r...9

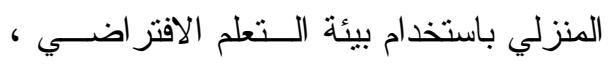
؛) (Eskrootchi \& Oskrochi , 2010

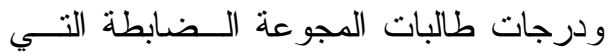
درست مقرر الاقتصاد المنزلــي باســتخدام (محمد محمود عبد الوهاب، 10 • ب)، (هويدا الطريقة التقليدية.

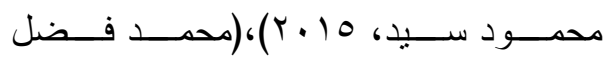

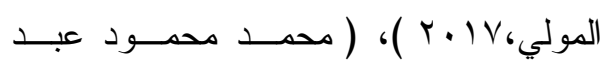

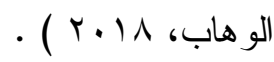
وبذلك تم الإجابة على الـسؤال الأول مـن

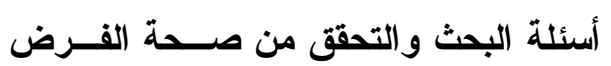
الأول - المنال وهـــا يعنـــي أن در اســـة طالبــات

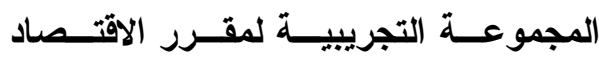




$$
\begin{aligned}
& \text { الخبرات التعليمية وتحسين التحـصيل } \\
& \text { المعرفي لدى الطالبات. } \\
& \text { و التي أكدت على أهمية بيئات الــتـعلم } \\
& \text { الافتر اضية في تحسين مـستوى التحـصيل } \\
& \text { • المعرفى الافزئ } \\
& \text { - المز ايا التي تتمتع بها المنصـة التعليميـــة } \\
& \text { Schoology } \\
& \text { و الرقم السري الموحد للصفحة الرئيسية } \\
& \text { و الصفحات الفرعية - الربط بين أدوات }
\end{aligned}
$$

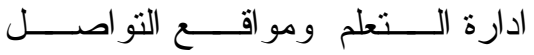

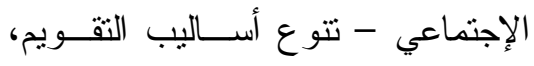

$$
\begin{aligned}
& \text { ساعد في تحقيق إيجابية الطالبة أنثــاء } \\
& \text { التعلم مما ساعد على الاحتفاظ بالمـادة }
\end{aligned}
$$

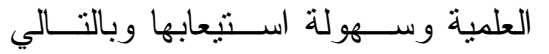

$$
\begin{aligned}
& \text { تحسين التحصيل المعرفي. } \\
& \text { - استخدام بيئة التعلم الافتر اضية ساهم في }
\end{aligned}
$$

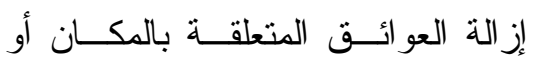

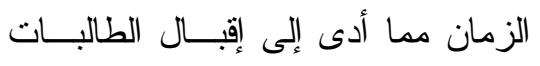

$$
\begin{aligned}
& \text { على التعلم بحب ومتعة و التخلص مـن لـن }
\end{aligned}
$$

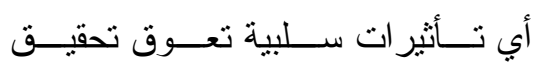

$$
\begin{aligned}
& \text { إيجابيتهن أثناء التعلم • } \\
& \text { - الشغف الألكتروني المتمنل في رغبـــة } \\
& \text { عينة البحث في الاستفادة من النطـــور }
\end{aligned}
$$

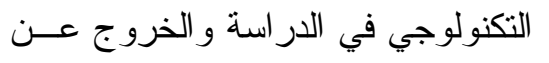

$$
\begin{aligned}
& \text { تزجع الباحثة هذه النتائج إلى: } \\
& \text { - نوفر بيئة الــتعلم الافتر اضــية تغذيـــة } \\
& \text { راجعه فورية عن مدى صحة إجابتهن }
\end{aligned}
$$

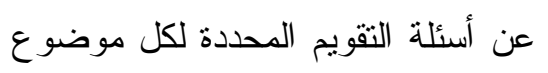

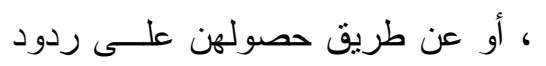

$$
\begin{aligned}
& \text { على أي استفسار حول الموضوع الذي دوني }
\end{aligned}
$$

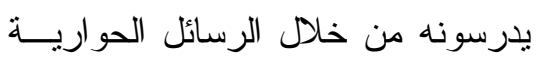

$$
\begin{aligned}
& \text { مع الباحثة، وتنساعد التخذيـــة الر اجعـــة }
\end{aligned}
$$

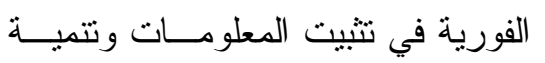

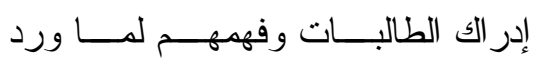

$$
\begin{aligned}
& \text { بالمقرر من مفاهيم ومعلومات وحقائق. } \\
& \text { - تتوع مصادر التعلم و أساليب الدعم التي } \\
& \text { تحصل عليها الطالبة (صفحة المحتوى } \\
& \text { العلمي- روابــط ويــبـ- فيــيوهات }
\end{aligned}
$$

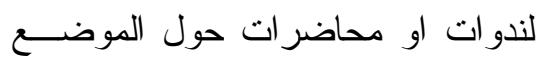

$$
\begin{aligned}
& \text { الذي يتم در استه- صـــور ورســومات }
\end{aligned}
$$

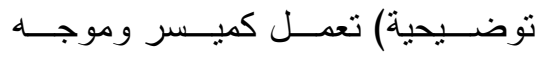

$$
\begin{aligned}
& \text { للطالبات مما ساعد في تبـسيط المـــادة } \\
& \text { النمط التقليدي في التعلم ســاهم فــي ولكي } \\
& \text { تكوين دافعًا للتعلم لدى الطالبات شــــع } \\
& \text { على زيادة تحصيلهن المعرفي. }
\end{aligned}
$$

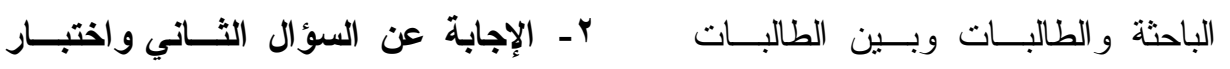

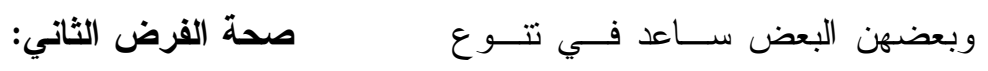


الحياة بين طالبــات المجموعـــة التجريبيـــة قد نص السؤال الثاني للبحث على: اللاتي درسن بواسطة بيئة التعلم الافتر اضي "ما أثز استخدام بيئة تعلم افتر اضــية

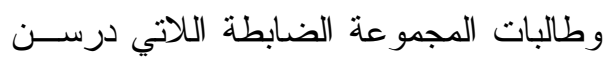
بالطريقة التقليدية." ولإججابة عن هذا السؤال و التحقق من قائمة على الفصول الإفتر اضية في تحسسين جودة الحياة لدى طالبات برنـــامج التأهيـلـل صحة هذا الفرض تم حساب دلالمة الفــروق بين متوسطي نتــائج طالبــات المجموعــة التجريبية و الضابطة في مقياس جودة الحياة

$$
\begin{aligned}
& \text { التربوي بكلية التزبية بسو هاج؟ " } \\
& \text { ونص الفرض الثاني للبحث على: }
\end{aligned}
$$
توجد فروق ذات دلالة إحصائية عند مستوى دلالة (2>05) في مقياس جـودة جدول ( ) (r)

نتائج تطبيق اختبار مان وتنى لمعرفة الفروق بين متوسطي نتائج طلاب المجموعة التجريبية

\begin{tabular}{|c|c|c|c|c|}
\hline مستوى الدلالة & مان ويتنى & المتوسط & العدد & المجموعة \\
\hline \multirow{2}{*}{$\cdots$} & \multirow{2}{*}{$\ldots$} & $1 \varepsilon$ & $r V$ & ضابطة \\
\hline & & $\leq 1$ & rV & تجريبية \\
\hline
\end{tabular}
و الضابطة في مقياس جودة الحياه الإكتروني.

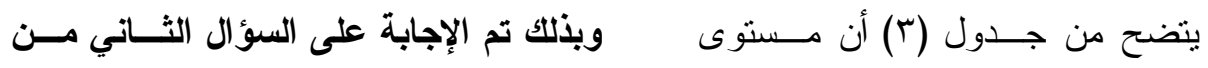

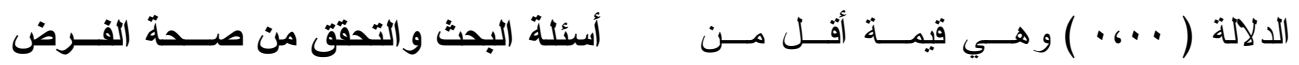

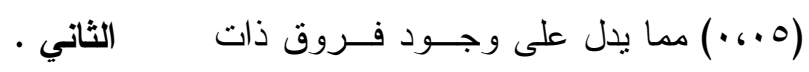
و هــذا يعنــي أن در اســـة طالبــات دلالة إحصائية في مقياس جودة الحياة بـين

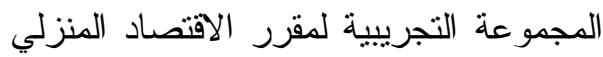
منوسطي درجات طالبات المجوعة التجريبية

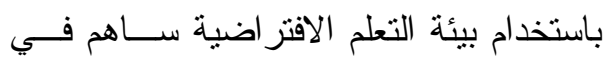

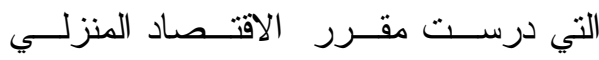

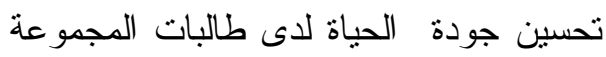
باستخدام بيئة التعلم الإفتر اضية ، ودرجــات

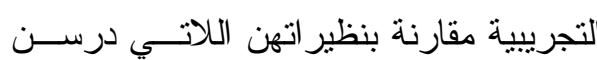
طالبات المجوعة الضابطة الثي درست مقرر

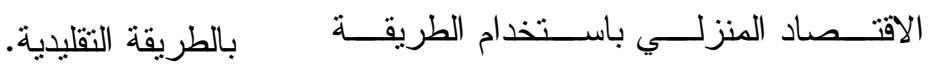
التقليدية. 
- توفر بيئات التعلم الافتراضية فرصنًا بديلة للتعلم التقليدي بسلبياته مما يتـيح الفرصة للطالبة المعلمة لنطوير كفاءتها

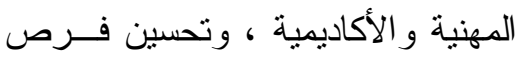
التعلم مما يحسن مسـن جــودة الحيــاة لايها.

- - استخدام بيئات التعلم الافنر اضية فـي التدريس لطالبات مجموعة البحث ينمي لديهن شعور بالكفاءة الذاتيــة وإجــادة التعامل مع متحديات العصر ، وشعور بالتحسن في النو احي الثقافية و التعليمية ؛ مما يحقق لديهن مفهوم جودة الحياة.

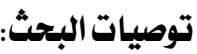

1 ـ الاهتمام بمفهوم تحسين جودة الحيــاة

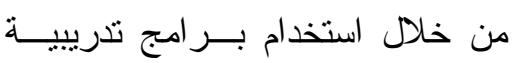
لاكساب المتعلمين المهار ات والقدرات اللازمة لتحسين جودة الحياة لديهم. r- التركيز على استخدام مداخل تعليميـــة و اساليب تدريسية حديثة والنظلي عن الطرق التقليديــة بـسلبياتها لتحسـين جودة الحياة التعليمية. r- توجيه الاهتمام لاستخدام تكنولوجيــا

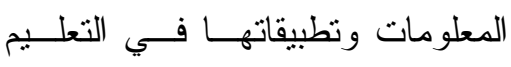
و الـــتعلم وخاصـــــة بيئـــات الــــتعلم

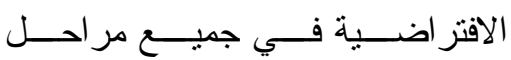

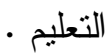

\section{وتتفق مع نتيجة البحث الحالي نتيجة دراسة}

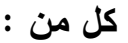

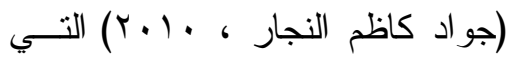

أكدت على أهمية اســتخدام بيئـات الــتعلم

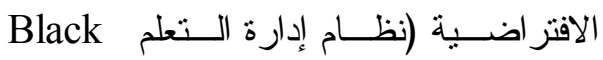
board

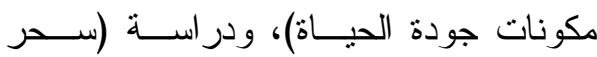

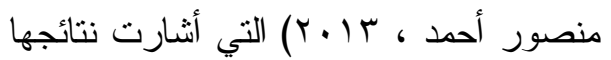
إلى فعالية استخدام برنامج تدريبي باســتخدام مو اقع التو اصل الاجتهـــاعي فــي مـسـاعدة المر اهقين الصم في تحسين جــودة الحيــاة لديهم.

\section{وترجع الباحثة هذه النتائج إلى:}

- أساليب التو اصل المتتوعة بين الباحثة

و الطالبات و التي توفر ها بيئة الــتعلم

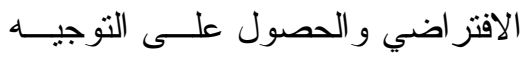
و الإرشاد وكذلك التغذية الر اجعة التـي لتصي تتلاقاها الطالبات حول مدى تقـدمهن التعليمي وصحة إجاباتهن عن أســئلة

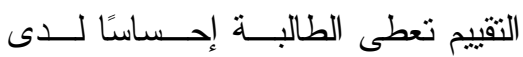

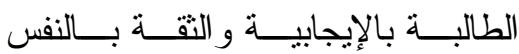

$$
\text { و الرضا . }
$$

- الذاتية في التعلم من خلال بيئات التعلم

الافتز اضية تكسب الطالبـات شــعورًا

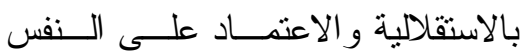
و الحماس و الاقبال على الحياة. 


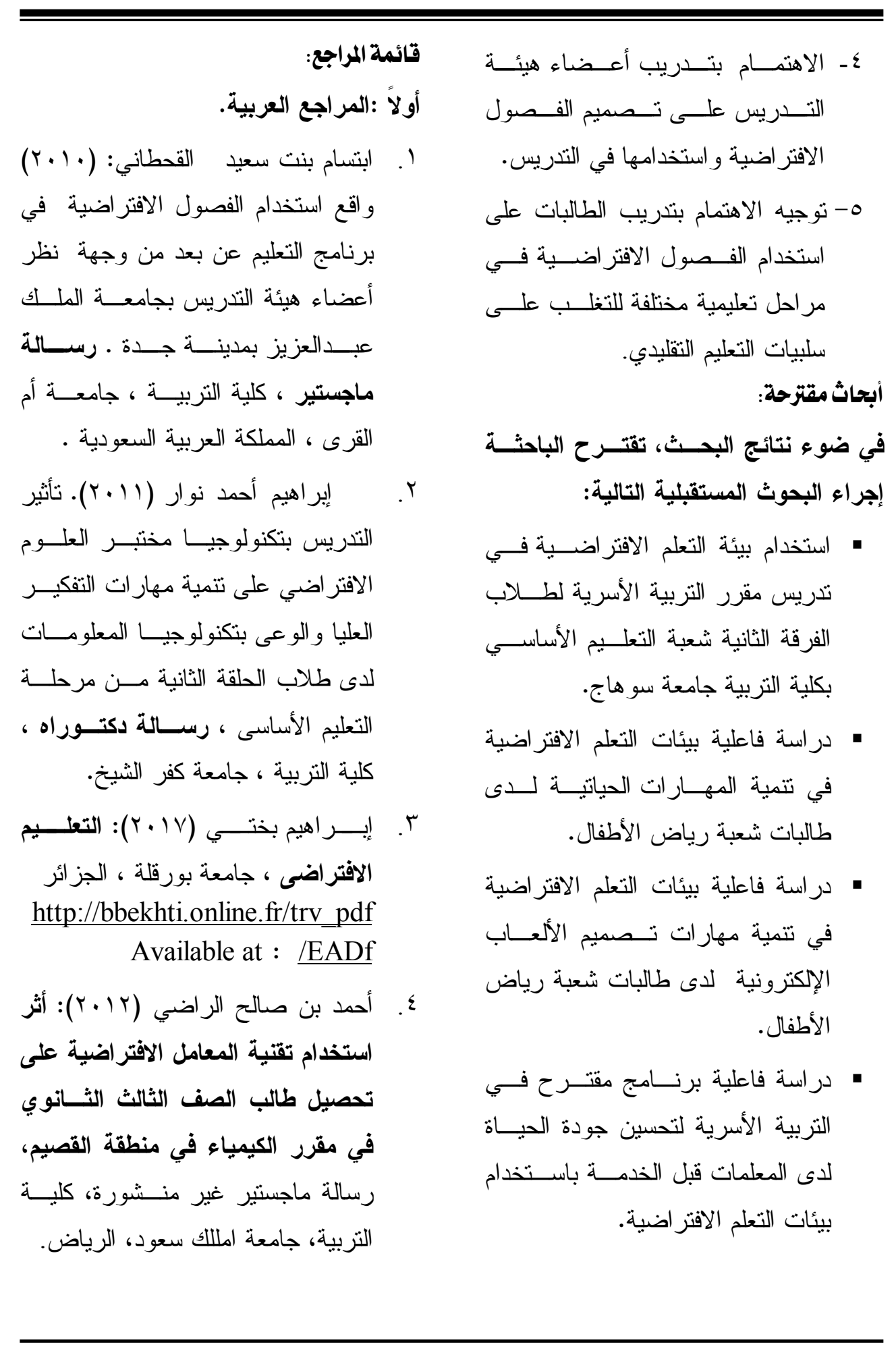




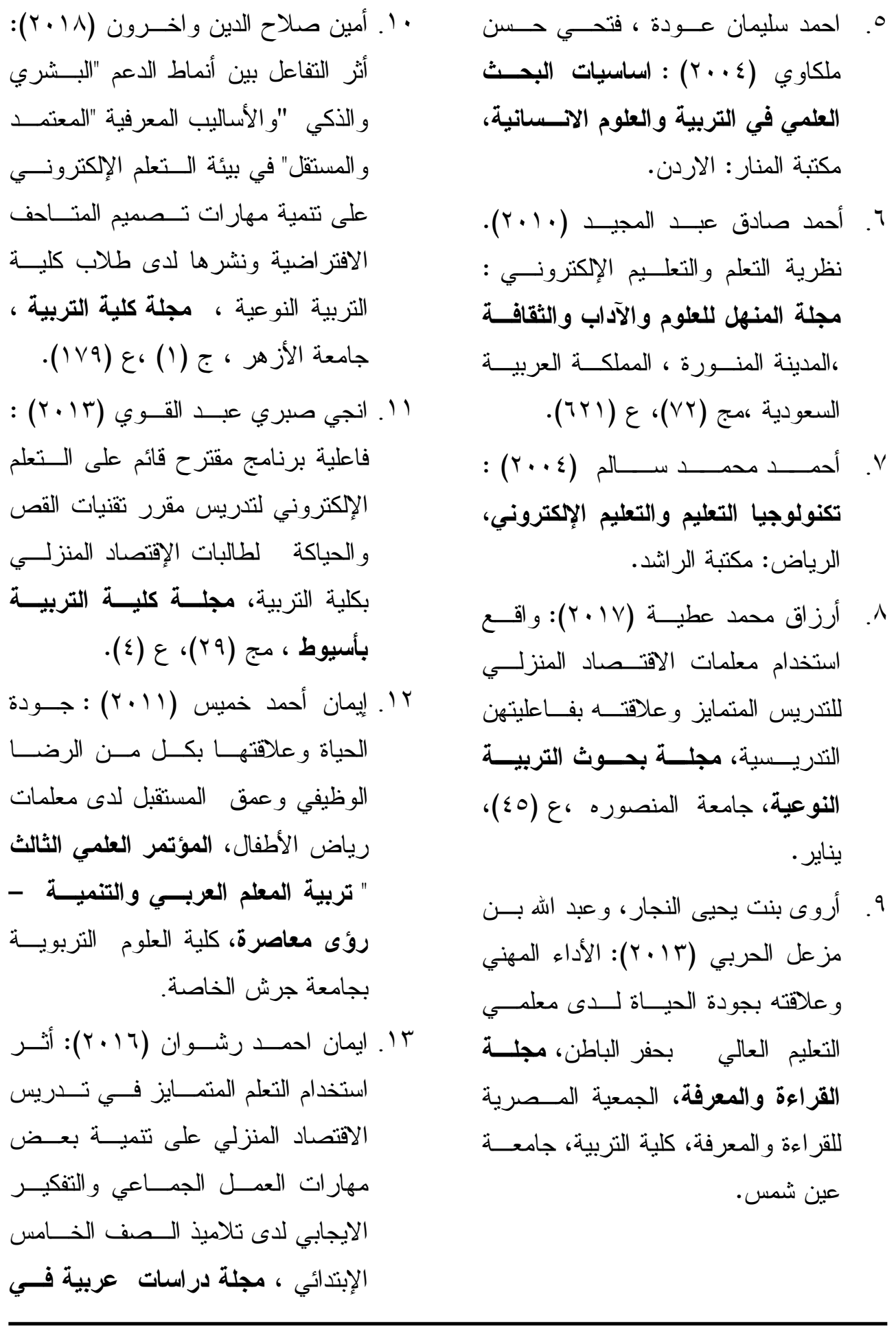




$$
\begin{aligned}
& \text { الاراسات التربوية ، تكنولوجيا التعليم } \\
& \text { والتعلم ... نشر العلم حيوية وإبداع ، }
\end{aligned}
$$

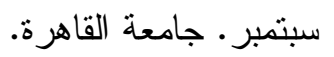

$$
\begin{aligned}
& \text { 1 ا. حسن مصطفى عبد المعطي (0. . Y). }
\end{aligned}
$$

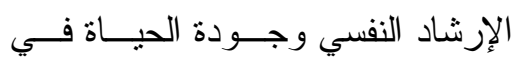

$$
\begin{aligned}
& \text { المجتمع المعاصر . وقـــائع المــؤتمر }
\end{aligned}
$$

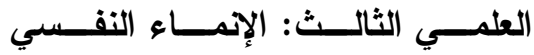

$$
\begin{aligned}
& \text { والتربوية للإنسان العربي في ضـــوء الإعـ } \\
& \text { جودة الحيــاة ، جامعــة الزقــازيقـ }
\end{aligned}
$$

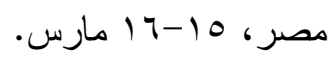

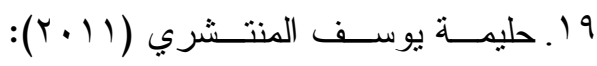

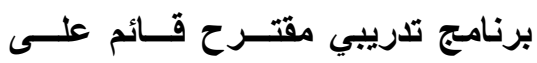

$$
\begin{aligned}
& \text { الفصول الافتراضية في تنمية مهارات }
\end{aligned}
$$

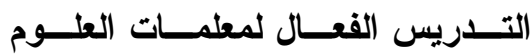

$$
\begin{aligned}
& \text { الثرعية ، رسالة ماجـستير ، كليــة }
\end{aligned}
$$

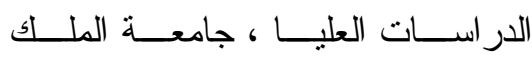

$$
\begin{aligned}
& \text { عبدالعزيز ، المملكة العربية السعودية. }
\end{aligned}
$$

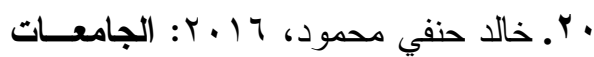

$$
\begin{aligned}
& \text { الافتراضية ومشكلات التعليم الجامعي } \\
& \text { 'العربــ2100 }
\end{aligned}
$$

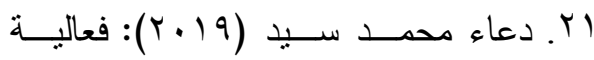

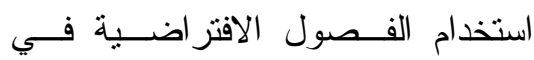

$$
\begin{aligned}
& \text { تدريس مقرر طرق التدريس على تتمية } \\
& \text { مهار ات التدريس الفعال ، مجلة كليــة }
\end{aligned}
$$

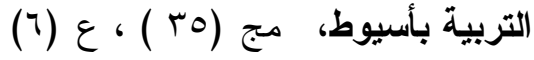

$$
\begin{aligned}
& \text { ، بونيو }
\end{aligned}
$$




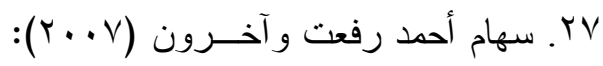

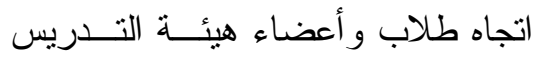

بكلية الاقتصاد المنزلي جامعة المنوفية نحو التعليم الإككتروني و علاقته ببعض الافي

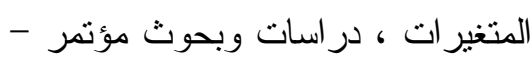

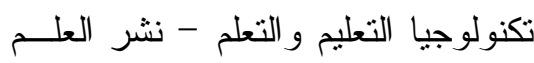

.... حيوية الإبداع.، الجمعية العربيــة

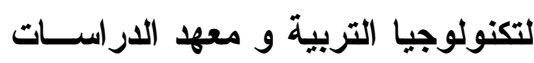

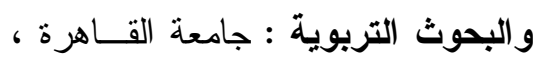
سبتمبر -

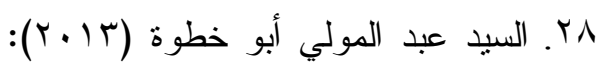
فاعلية برنامج مقترح قائم على التدريب

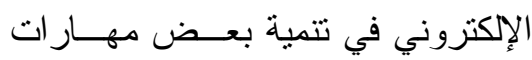

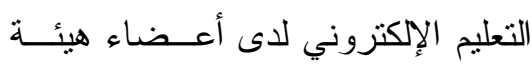
التذريس. بحث مقدم الى مؤتمر التعلم

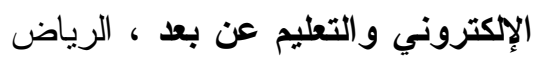
: المملكة العربية السعودية.

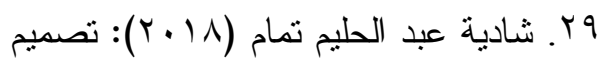
بيئة تعلم إلكترونية قائمة على الفصول

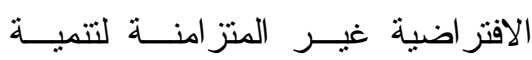
مهار ات التذريس في مقـرر التــدريس

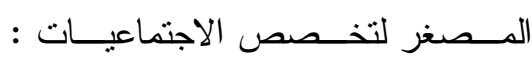
دراسة حالة على طلاب كلية الدر اسات

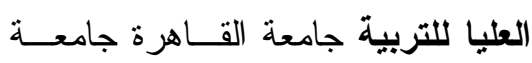

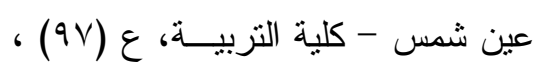
• بناير

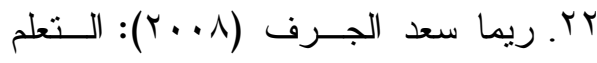

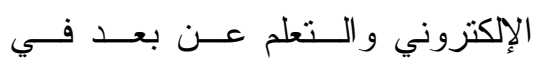

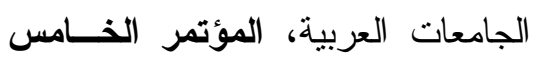

لمنظمة آفاق البحث العلمي والتطــور

التكنولوجي في العالم العربي ، فــاس،

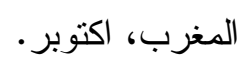

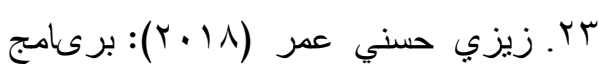

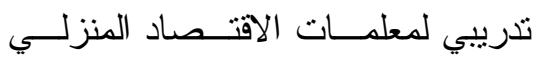

لتحسين التتور التكنولــوجي والاتجـــاه

نحوه في ضوء معايير جودة التعلـيم

الإكتروني، مجلة دراسات عربيـة فئة

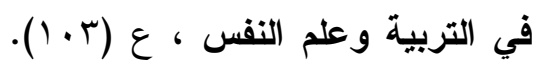

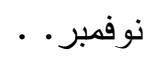

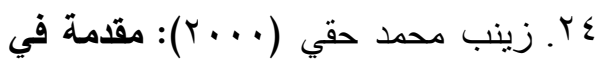

الاقتصاد المنزلي، القاهرة: مكتبة عين

شمس .

هr. سحر منصور أحمد ، با •r: فعاليــة

برنامج تدريبي باستخدام مو اقع التــو ال

الاجتماعي في تحسين جــودة الحيــاة

للمر اهقين الصم ، مجلــة دراســات فئس

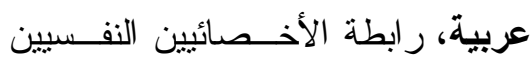

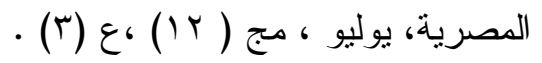

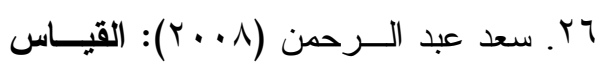

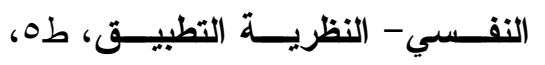

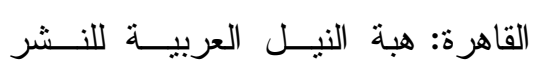
و التوزيع. 
Hhttp://www.emigration.gov.eg, Available At:

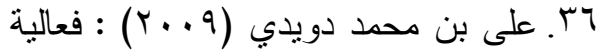
التعلم الإلكتروني في تتميــة مهــارات

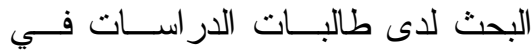
جامعة طيبة، مجلة العلــوم العربيــة و الإنسانية، جامعة القصيم ، ب (1).

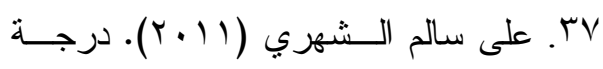
وعى أعضاء هيئة التدريس في جامعة

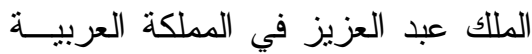
السعودية بنظام الفـصول الافتز اضـــية

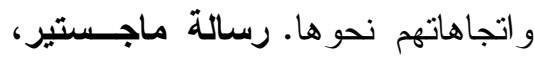
كلية الدر اسات العليا، الجامعة الأردنية.

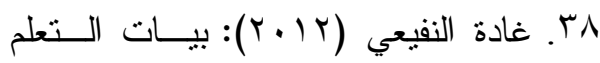

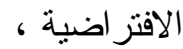

http://altadreeb.net/articleDetails.p hp? $\mathrm{id}=662$ \&issueNO $=23$

Available at:

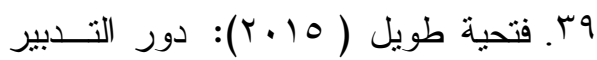

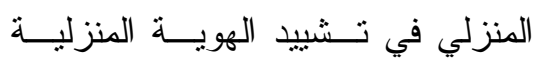

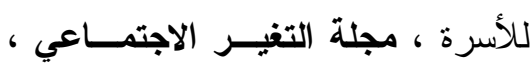

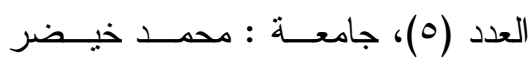

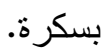

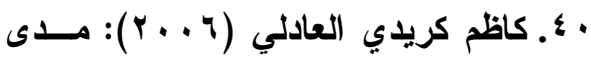
إحســاس طلبــة كليــــة التربيـــــة

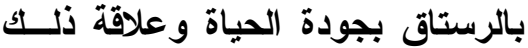
ببعض المتغير ات. وقائع نــدوة علـــ النفس وجودة الحياة ،جامعة الـسلطان
• ب. عبد الله عبدالعزيز الموسوي و احمـــ

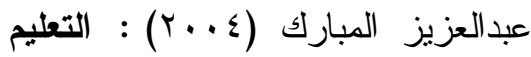

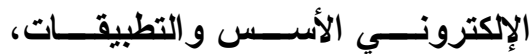
الرياض: شبكة البيانات .

اسب. عبد الحكيـم رضوان حافظ ، أحمـــ

محمد أحمد (Y...Y): الرضا عن جودة الحياة الوظيفية لدى معلمـي التعدــيم الثانوي الصناعي بجمهوريــة مـصر العربية، رسالة ماجستير، كلية التعـــيم الصناعي، جامعة قناة السويس.

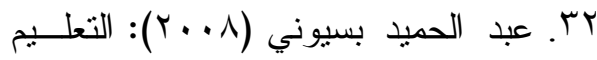

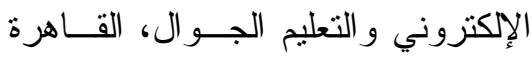
:دار الكتب العلمية.

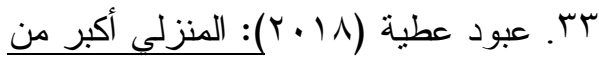
إلقائه على عاتق فرد مــن الأسـرة ،

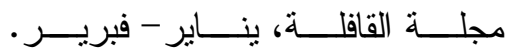
Available at: https://qafilah.com/ ع ب. عبير أحمد أنور، فــاتن عبدالــصادق

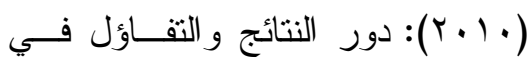
النتبؤ بنوعية الحياة لــدى عينــة مــن

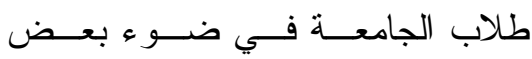
المتغيـــر ات الديموجر افيــة، دراســــات

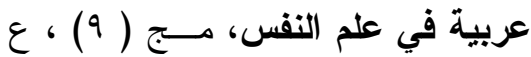

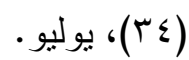

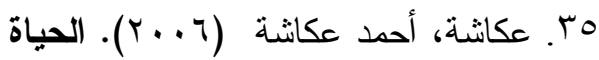

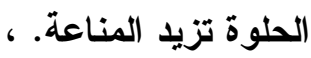


بكلية التربية بسوهاج، مجليــة كليــة

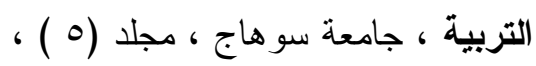

$$
\text { عدد (ro). }
$$

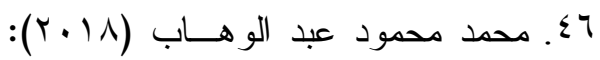

فاعلية استخدام بيئة تعلَّم افتر اضـــية

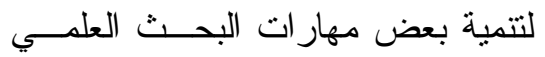

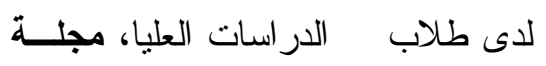

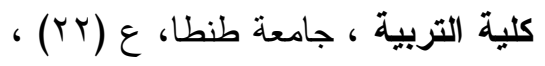

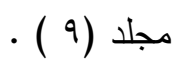

₹ V محمود عبد الحليم منسي؛ وكاظم، علي

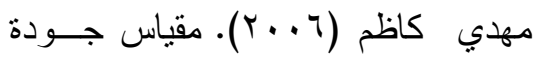

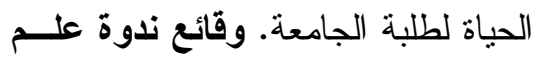

النفس وجودة الحياة ، جامعة السلطان

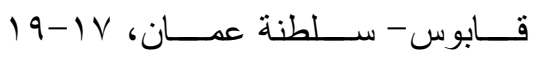

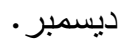

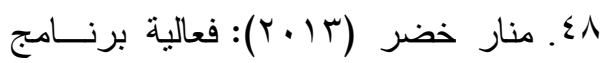

الكمبيوتز المصمم نحو تتميــة الاتجـــاه

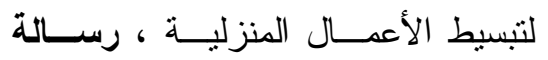
دكتور اه ، جامعة المنصورة.

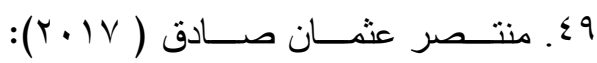

برنامج تدريبي مقتر ح لإكساب مهار ات

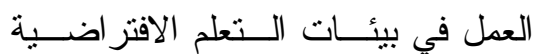

لأعضاء هيئة التدريس الجامعي وأتــره

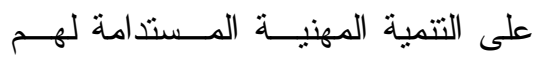

،مجلة العلوم التربوية: جامعة القاهرة

$$
\begin{aligned}
& \text { ق قـابوس - ســلطنة عمــان، IV- } \\
& \text { ديسمبر - } \\
& \text { اءـ كيلاني عبد الرحمن الكناني (10 • ب): }
\end{aligned}
$$

العلاقة بين جـودة الحيــاة الددرســية العـية

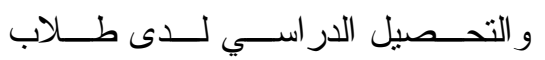

المرحلة الثانويسـة ـ مجلــة الإرشــاد

$$
\text { النفسي، ع (1) }
$$

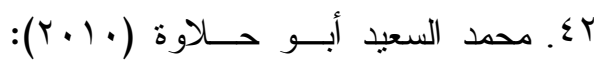

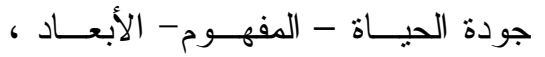

المؤتمر العلمي السنوي لكلية التربية ، التودة ،

جامعة كفر الشيخ

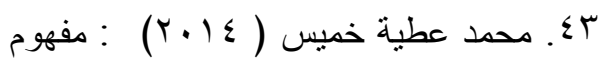

بيئات التعلم الافتر اضـــية ، الجمعيــة

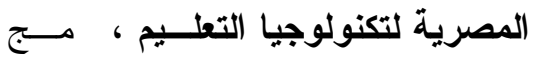

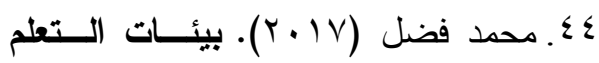

الافتر اضي ونظم إدراتها ، مقال منشور

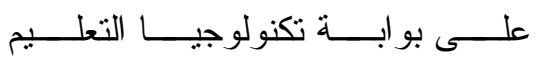
http://drgawdat.edutechportal.net/archives/15020

Available at:

0. محمد محمود عبد الوهـاب (10 بـ):

فعالية برنامج مقترح في استخدام نظام

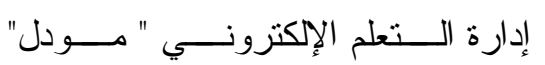

في التّريس و أثزه علــى (Moodle)

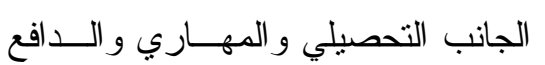

للإنجاز لاى طلاب التعلــيم التجــاري 
icat/dil-papers-2/Dil.7.5.18.pdf

Available At:

00. ياسر بن محمد الغريبي (9 . . Y) : أثر

التنريس باستخدام الفصول الإكترونية

بالصور الثلاث (تفاعلي - تعساوني -

تكاملي ) على تحصيل تلاميذ الـصف لـف

الخامس الابتدائي في مادة الرياضيات ،

رسالة ماجستير ، كلية التربية ، جامعة

$$
\text { أم القرى ، السعودية. }
$$

ثانيًا : المراجع الاجنبية

2-Harris A, \& Rea A., (2009):

Web 2.0 and virtual world techniques A growing impact of the education . Journal of information system education (20) 2 .

3-Barcaccia, B. (2013): Quality Of Life: Everyone Wants It, But What Is It? . Forbes/ Education.

Retrieved 10

May 2016

4-Costanza, R.; et al. (2008): "An

Integrative Approach to

Quality of Life Measurement,

Research,

Policy". S.A.P.I.EN.S.( 1 ) 1.

5-Young,P.A.(2009):

Instructional

design

frameworks and intercultural modeles. New York

:Information Science reference, Hershey.

6-Alkaram , A.M., \& Al- Ali N.M.

(2001): E- learning: the New
- كلية الدراسات العليا للتربيـــة مـــج .

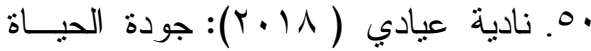

الأسرية لاى طلبــة الجامعــة. مجلـــة

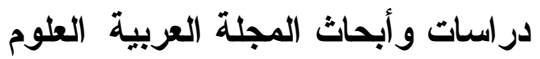

الإنسانية والاجتماعية ، مجلـــ (• (1)،

عدد (乏).

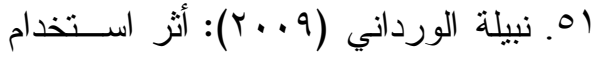

الوسائل التعليمية الحديثة فـي تــدريس

المقرر ات الجامعية ، المؤتمر الــدولي

$$
\text { للتعلم الإكتروني بالبحرين. }
$$

Or. or

التتبؤية لفعالية الذات و الدافعية للإنجاز

بجودة الحياة لــدى طالبــات مرحلـــة

الدراسات العليا بكلية التزبية مجلة كلية

التربية في العلوم التربويـــة ،جامعــة

عين شمس ، مجلا (•ـ) ،ع (1).

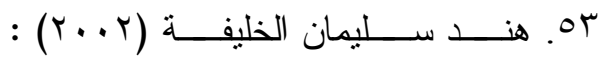

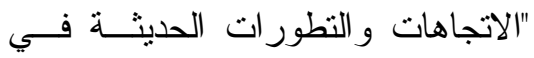

خدمة التعليم الالكتروني در اسة مقارنة

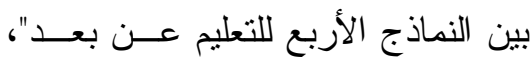

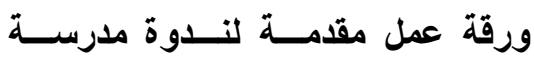

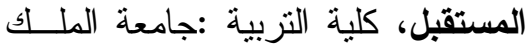

سعود، الفترة من 17 - 17 شعبان.

§. هيام حايك (ع ( ب): كيف أصبح التعلم

الإفتر اضي ضرورة في عصر الرقمنة

http://tecfa.unige.ch/tecfa/publ 
context: what are major pathways linking leisure to Quality of life . social Indicators Research 82(2), 233-264 .

13-Tayler , M.(2005): Motivation of adolescent students toward saccess in school Eileen Friday . http.//by Fgcu.edu./1-4

14-Weller, Martin (2007). Virtual learning environments: using, choosing and developing your VLE. London: Routledge. pp. 4 5. ISBN 9780415414302.

15-Sara Jonson ( 2019): The Advantages and Disadvantages of a Virtual Learning Environments . Available at: https://www.knowledgeanywh ere.com/resources

16L Richin and., O, Safie., A, Horspool., S,(2009): McKinney- 25 in Students Disabled-Learning with Life Second Using Online of Journal: INNOVATE, Education Higher, (4)3.

17-Modritscher, F. (2006). ELearning theories in practice: a comparison of three methods. Journal of Universal Science and Technology of Learning.n.5 .

18-McNally, James W. (2009). Encyclopedia of the
Breed of Education, In Billeh, Education Development through Utilization of Technology: UNESCO Regional Office for Education in the Arab States", pp. 49-63

7-UNESCO,(2002): Open and distance :Trends, policy and strategy consideration, Paris :UNESCO.

8-Rice, W.H.(2009): Moodle 1.9 e -leaning course development :a complete guide to successful Learning using moodle ,Birmingham, UK ;pact.

9-Sarikaya,O. (2010): The impact of a faculty development pogram : evaluation based on the self- assessment of medical education from preclinical and clinical, disciplines,Advances in physiology Education.

10-Potter,C .\& Naidoo, G. (2012): Teacher development through distance education :contrasting visions of radio learning in south African primary

11-Richard F., (2005):The impact of virtual classroom on teaching and learning in education as perceived by teacher library media, ERIC ,document production . no ED 410943.

12-Lwasski, y. (2007): Leisure and Quality of life in an international and multicultural 
journal of open distance and e- learning. Vol. (4). No (65).

22-Ben D., et- al, (2003): Social Capital in Virtual Learning Communities and Distributed Communities of Practice. CJLT Volume 29, Number 3, Oct 15, 2003 ISSN $1499-6677$ e-ISSN 1499-

6677 Publisher: Canadian

Network for Innovation in Education

23-Barbara S., (2018): Virtual Learning Environment https://blog.hotmart.com/ar

24-Helen A. (2011) : World home economic day aims to improve quality of life.
Life Course and Human Development.vol.(3) ,USA: Macmillan Reference.

19-Longest J. (2008). Quality of life impact in mental health needs, New York, Institute of Education Sciences

20-Ancthil T. Mc Cubbin L. O Brien K. Pecora P. and Anderson H. (2007): Predicators of adult quality of life fir foster care alumni with physical and - or psychiatric disabilities, Child Abuse and Neglect, the international journal, Vol 31, No 10.

21-Alias N., (2005): Supportive distance learning environment : A Study on the learning support needs on malisian online learner .The urpian 